\title{
Effect of Injection Parameters: Injection Timing and Injection Pressure on the Performance, Emission and Combustion Characteristics of CRDI Diesel Engine Operate with Palm Oil Methyl Ester (POME)
}

\author{
Mahantesh M. Shivashimpi ${ }^{1}$, Nagaraj R. Banapurmath ${ }^{2 *}$, S. A. Alur ${ }^{1}$ \\ ${ }^{1}$ HIT, Nidasoshi, INDIA \\ ${ }^{2}$ KLE Technological University, B.V.B, College of Engineering and Technology, Hubballi, Vidyanagar, INDIA
}

*Corresponding Author: nrbanapurmath@gmail.com

Citation: Shivashimpi, M. M., Banapurmath, N. R. and Alur, S. A. (2019). Effect of Injection Parameters: Injection Timing and Injection Pressure on the Performance, Emission and Combustion Characteristics of CRDI Diesel Engine Operate with Palm Oil Methyl Ester (POME). European Journal of Sustainable Development Research, 3(3), em0091. https://doi.org/10.20897/ejosdr/3977

Published: March 21, 2019

\begin{abstract}
This experimental study mainly focused on the investigation of CRDI diesel engine powered with palm oil methyl ester (POME) biodiesel and diesel fuels. The Toroidal Re-entrant combustion chamber shape (TRCC) and 6 holes CRDI injector were selected for experiment. The current research engine operated with constant CR 17.5 and speed $1500 \mathrm{rpm}$. In the first phase of work, the injection timing (IT) varied from -25 ${ }^{\circ} \mathrm{BTDC}$ to $5^{\circ} \mathrm{ATDC}$ with interval of 5 degree during the experiments. The injection time- $10^{\circ} \mathrm{BTDC}$ has been optimized for higher engine efficiency. In the second phase of work, the injection opening pressure (IOP) has been varied form 600 bar to 1000 bar with increment of 100 bar interval during the experiments. The IOP of 900 bar has been optimized with constant fuel IT $-10{ }^{\circ}$ BTDC. Finally, the end results of experiments were reported that combined effects of IT $\left(-10^{\circ} \mathrm{BTDC}\right)$ and IOP (900 bar) enhanced the engine output in terms of brake thermal efficiency (BTE), also minimizing the pollutants using TRCC shape and 6-hole CRDI injector for CRDI diesel engine at 80\% load.
\end{abstract}

Keywords: palm oil methyl ester (POME), common rail direct injection (CRDI), injection strategies, performance, combustion and emission characteristics, toroidal re-entrant combustion chamber shape (TRCC)

\section{INTRODUCTION}

The biodiesel has been used in the conventional engine by using various methods and techniques reported as many as works (Murugesan et al., 2009; Atadashi et al., 2010; Banapurmath et al., 2009). Now a day's fossil fuels are using tremendously, but these are not promising as sustainable energy resources, because fossil fuels are decaying very soon and emits more pollutants to environment and creating the health problems on living beings. Hence it is very much necessary to switch over to utilization of alternative renewable sources (Naik et al., 2010). The advantages of diesel engine are higher BTE, outstanding drivability but they emit more quantity of particulate matters and NOx. Some of emission norms are developed by various agencies to control the pollution from diesel engines (Mani et al., 2011). To resolve all problems of CI engines, many research works has been carried out worldwide with various fuel combinations and injection strategies (Atmanli et al., 2014; Gautam and Agarwal, 2013). Trans-esterified biodiesel fuel has very stringent potential in CI engines, hence as many as countries uses the varieties of edible and non-edible oils such as palm, soybean, Jatropha curcas, pongamia pinnata and linseed 
biodiesel to produce the power output from CI engine (Srivastava and Verma, 2008; Balat and Balat, 2008; Dixit and Rehman, 2012; Labeckas and Slavinskas, 2006; Kannan et al., 2012). The application of such biodiesels for diesel engines were minimized the pollutants such as particulate matter (PM) emissions, carbon hydrocarbon (HC) and carbon monoxide (CO). Hence the drastic improvement was essential requirement in the field of biodiesel fueled diesel engine. The end products of tyre pyrolysis are carbon black, pyro gas and oil (Paul and Williams, 2013). A reduction of BTE, when blend ratio was increasing in standard diesel fuel reported in the literature survey (Abhishek and Murugan, 2013). As per report of experiment depicted that reduces the CO, smoke level and HC emissions when addition of Desulfurized tyre oils mixed with diesel, but comparatively diesel has lower emission than mixed oil (Aydın and Ilk1lıc, 2015). When plastic oil blends with diesel gives higher SFC than diesel and higher of CO, NOx and $\mathrm{CO}_{2}$ emissions were observed (Pratoomyod and Laohalidanond, 2013). Many research works have been carried on CI engine by using several biofuels with different injection strategies as IT and IOP. By advancement or retardation in IT, there was enormous changed in combustion parameters has been observed (Hountalas et al., 2001). As retarding the IT in CI engine, the NOx pollutant has been reduced when operated with biodiesel and diesel fuels (Hountalas et al., 2001; Tao et al., 2005). The tremendous cylinder pressure and temperature were decreased has been observed when IT was retarded in CI engine (Roy, 2009). The IT effect was observed at advanced IT of $40^{\circ} \mathrm{BTDC}$ when waste cooking oil operated as biofuel in CI engine and reported that better BTE and reduced pollutants (Bari et al., 2004). Honge biodiesel has been reported that the performance of CI engine improved by retarding the IT (Banapurmath et al., 2008). The engine performance has been improved by enhancing the IOP up to $230 \mathrm{bar}$ and retarding the IT, when cotton methyl ester operates in CI engine (Rosli et al., 2008; Banapurmath et al., 2012). The experimental results showed that the pollutants CO, PM and HC emissions were minimized by the percentage of $14.2 \%, 13.26 \%$ and $9.3 \%$ respectively, when CI engine operated with JOME and pyrolysis blend at advanced IT condition of $24.5^{\circ} \mathrm{CA}$ BTDC (Sharma and Murugan, 2015). In the same way, by enhancing the IOP with various fuel combinations would result better performance of IC engine were reported by many experimental research works (Roy 2009; Banapurmath et al., 2008; Rosli et al., 2008; Sukumar et al., 2009; Suresh et al., 2013).

The various research works have been carried out on CI engine with modification of nozzle holes geometry operated with biodiesel fuel. Ten holes nozzle geometry performed well in terms of better atomization and reduction of NOx emission in diesel engine at full load condition (Karra et al., 2010). Suggested that by varying number holes in nozzle injector reducing the oxides of nitrogen in biodiesel fuelled diesel engine and minimize the unburnt hydrocarbon, carbon monoxide and brake specific fuel consumption (Lahane et al., 2014). By varying the injection timing, injection pressure, CR and nozzle holes leads to enhance the performance parameters like brake thermal efficiency, meanwhile reduced the emission characteristics in biodiesel fuelled diesel engine but however oxides of nitrogen emission has been increases as number of holes increase in injector nozzle (Khandal et al., 2015). Suggested that, retarded IT of $19{ }^{\circ} \mathrm{bTDC}$, IOP of $230 \mathrm{bar}$ and four-hole nozzle injector were optimized injection parameters for higher BTE with lower emissions operated with HOME, HnOME and COME fuels in CI engine (Wategave et al., 2014). Many research works have been carried out by modification in both combustion chamber shapes and injection strategies. The experimental results were observed in CI engine operated with Pongamia biodiesel fuel, the BTE of engine has improved as compared to baseline HCC shape (Jaichandar and Annamalai, 2012). The experimental work has been reported that, both BTE and SFC were improved in CI engine operated with Pongamia biodiesel fuel for combination of TRCC shape and higher injection pressure (Jaichandar and Annamalai, 2013). Torroidal combustion chamber shape showed higher performance parameters with reduced emission characteristics compared to Cylindrical, trapezoidal combustion chamber shapes in diesel engine (Banapurmath et al., 2015). The combined effect of cylindrical combustion chamber shape and nozzle geometry reduced the NOx emission up to $45 \%$ as compare to baseline geometry, but reduced slightly in BTE parameter was observed in biodiesel fuelled diesel engine (Shivashimpi et al., 2017). Cylindrical combustion chamber shape performed better BTE up to B60 blend and $40 \%$ reduction of NOx was observed as compared to base line geometry in biodiesel fuelled diesel engine (Shivashimpi et al., 2016). By the modification combustion chamber shape led to the reduced emission characteristics but performance parameters remain same was observed in diesel engine (Mobasheri et al., 2013). By using combine effect of multi-chambered combustion chamber shape and 200 bar nozzle injection pressure showed better performance and reduced emissions in diesel engine operated with Jatropha biodiesel fuel (Rajashekhar et al., 2012). TRCC shape resulted higher BTE, reduction of SFC and emission characteristics at retarded injection timing compared to baseline combustion chamber shape when diesel engine operated with Ultra sulphur diesel fuel (Jaichandar et al., 2012). The engine operated with HOME - producer gas resulted increase in 4-5\% of BTE and reduced emissions with TRCC shape, 230 bar IOP and 4-hole nozzle geometry (Yaliwal et al., 2016). The BTE of Toroidal combustion shape found higher in performance but slightly lower in emissions parameters as compared with spherical and Toroidal re-entrant combustion shape operated with 20\% JTME in diesel engine (Mamilla et al., 2013). The BTE has improved by Toroidal combustion chamber with tangential cut on circumference of the piston crown and reduced emissions were observed at 200 bar IOP 25 
${ }^{\circ}$ BTDC IT as compared with base line shape in diesel engine (Kumar, 2017). The experimental investigation showed that higher BTE resulted for up to B40, B20 of POME blends in base line and modified CCC shapes respectively in diesel engine. In the same way, drastic reduction of UBHC and NOx emissions were observed in modified SCC and TCC shapes as compared to base line shape (Shivashimpi et al., 2018). The experimental report showed that in diesel engine, the fuel IT of $27^{\circ}$ BTDC, IOP of 240 bar, 5 holes nozzle geometry with Toroidal Re-entrant combustion chamber shape gave BTE with nominal emissions (Shivashimpi et al., 2018).

Now day's research woks were carried for CI engine by adopting CRDI technology. CRDI technology has very suitable for $\mathrm{CI}$ engine to improve the performance and reduce the emissions of engine. Many research woks have been conducted the experiments on CRDI engine with operating both diesel and bio derived fuels. The obtained results were compared with conventional CI engine. The CRDI diesel engine operated with Tung oil-diesel-ethanol blends has been improved engine efficiency and reduced emissions, but slightly NOx increased as compared to diesel (Qi et al., 2017). At 880 bar IOP was operated in the CRDI engine with mahua methyl ester blend showed better combustion performance and reduced HC, CO and smoke emissions (Aalam et al., 2016). The harmful pollutants have been decreased when biodiesel blend with nanoparticles in CRDI diesel engine (Aalam et al., 2017). Reduced emissions were observed for IP from 600 to 1200 bar in CRDI engine (Grimaldi et al., 2000). 40\% of particulate matter was reduced by using post and multiple injection strategies in CRDI diesel engine and improved addition combustion performance was also observed (Chen, 2000). Combustion process in CRDI diesel engine has mainly depended on the pilot injection; timing and quantity were observed (Bandai et al., 2001). Experiments were conducted the on common rail HSDI diesel engine operate with rape seed methyl ester (RME) showed lower $\mathrm{CO}$, smoke and $\mathrm{HC}$ emissions and slightly increase in the NOx levels. Performance and combustion characteristics were slightly lower for RME compared diesel was observed (Carlo et al., 2002). CRDI diesel engine IP affects the all the injection parameters like delivery of fuel, its duration and quantity under all modes of injection fuel strategies (Henein et al., 2002). The optimized engine variables like start of injection, injection duration and air fuel ratio were enhancing the power, lower bsfc and reduced emissions in CRDI diesel (Soorajith and Vinu, 2004). By varied the injection angles and increased the injection pressure were resulted faster combustion rate in combustion chamber along with increased NOx emission for CRDI engine (Fang and Lee, 2009). CRDI CI engine powered with karanja biodiesel was improved in thermal efficiency and reduced emissions up to 10\% of blend (Agarwal et al., 2015). Advanced start of injection timing showed higher performance, better combustion characteristics and lower bsfc and increased NOx was observed in CRDI CI engine (Agarwal et al., 2015). The CRDI mode diesel engine operated with HOME and COME BDF's gives the better performance and reduced with smoke and $\mathrm{NO}_{\mathrm{x}}$ emissions as compared to conventional diesel engine, when 7 holes CRDI injector, TRCC, 900 IOP and $10^{\circ}$ BTDC have been adopted in engine (Khandal et al., 2018). The diesel engine run with CRDI mode gave the reduced emissions of $\mathrm{CO}, \mathrm{HC}$ and smoke except $\mathrm{CO}_{2}$ and $\mathrm{NO}_{x}$ (Karthikeyan et al., 2018). The CRDI diesel engine showed that lower opacity for advanced combustion mode as compared to conventional diesel engine (Iorio et al., 2018) The CRDI operated diesel engine tested with plastic liquid fuel blends obtained from the municipal waste plastic pyrolysis process. The CRDI engine operated with plastic liquid blend showed improved performance than mineral diesel operation. Slightly, the emissions have been improved towards $\mathrm{CO}, \mathrm{HC}$ and $\mathrm{NO}_{\mathrm{x}}$ emissions (Shettyet et al., 2016). Thermal efficiency of CRDI diesel engine decreases up to $30 \%$ of plastic oil blend than diesel, but CO was increasing with increases in blend and $\mathrm{CO}_{2}$ and $\mathrm{NO}_{\mathrm{x}}$ were decreases as increasing in the blend (Shukla et al., 2016). The diesel engine with CRDI mode showed that B20 blend emitted lower primary particulates matter in comparison with mineral diesel at all loads (Shukla et al., 2014)

From exhaustive literature survey revealed that, experimental work was scantily carried on combined effect of IOP, IT, nozzle geometry and TRCC shape in CRDI diesel engine operated with POME as alternative fuel. Hence, experimental research investigation progressed herewith choosing POME as biodiesel and various IT and IOP with using TRCC shape and 6 hole injector for CRDI mode diesel engine.

\section{Objective of the Work}

The objective of research work is to optimize the injection timing and injection pressure for improve overall efficiency of CRDI diesel engine using TRCC shape and 6 holes CRDI injector operated with POME as a biodiesel fuel and compared performance, combustion and emission characteristics results of modified CRDI diesel engine operated with POME and diesel fuels.

\section{PRESENT WORK}

The present work basically involves the determination of POME biodiesel fuel properties and comparison with standard mineral diesel fuel. Effect of combustion chamber shape i.e., Toroidal re-entrant combustion chamber shape with 6 holes CRDI injector on the performance of diesel engine fuelled with for higher efficiency and lower 
Table 1. Properties of various fuels

\begin{tabular}{clccc}
\hline S1.No. & Properties & Diesel & PALM OIL & POME \\
\hline 1 & Density $\left(\mathrm{kg} / \mathrm{m}^{3}\right)$ & 840 & 890 & 380 \\
\hline 2 & Energy density $(\mathrm{kJ} / \mathrm{kg})$ & 43,000 & 36,400 & 38,400 \\
\hline 3 & Viscosity at $40^{\circ} \mathrm{C}(\mathrm{cSt})$ & $2-5$ & 43.28 & 280.5 \\
\hline 4 & Flash Point $\left({ }^{\circ} \mathrm{C}\right)$ & 75 & --- & 160 \\
\hline 5 & Cetane Number & $45-55$ & --- & - \\
\hline 6 & Carbon Residue $(\%)$ & 0.1 & --- \\
\hline
\end{tabular}

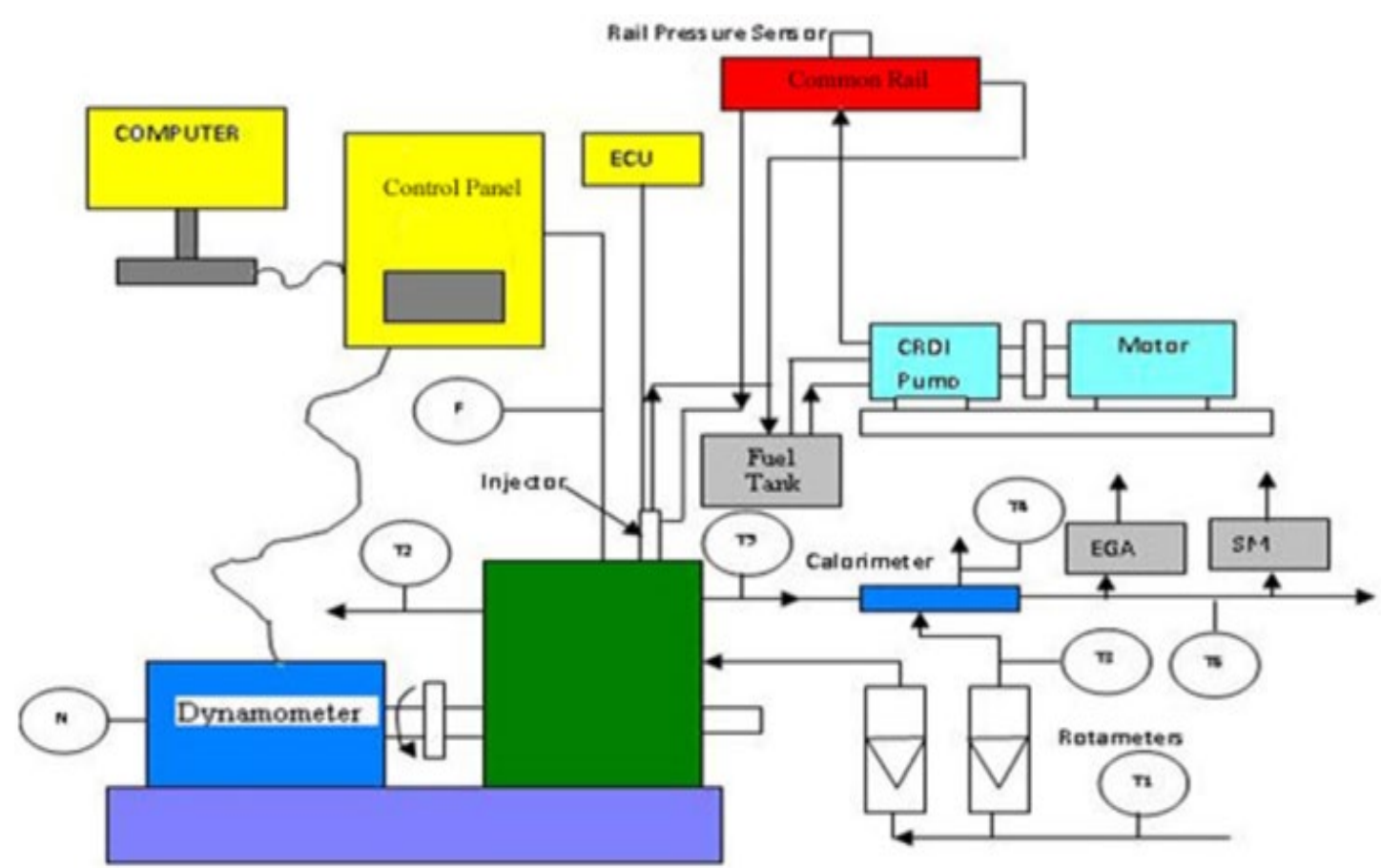

T1, T3 - Intake Water Temperature. T2 - Outlet Engine Jacket Water Temperature.T4 - Outlet Calorimeter Water Temperature T5 - Exhaust Gas Temperature before Calorimeter T6 - Exhaust Gas Temperature after Calorimeter F1- Fuel Flow DP (Differential Pressure) unit. N - RPM encoder, EGA - Exhaust Gas Analyzer, SM - Smoke meter

Figure 1. Schematic diagram of experimental set up and CRDI facility in modified CI engine

emission of engine. Finally, comparison of results between modified CRDI diesel engine operated with POME and diesel fuels.

\section{MATERIALS AND METHODS}

The above section mainly discussed the materials and methodology has been adopted for the experiment.

\section{The Details of POME Properties}

The important properties of POME are enlisted blow in the Table 1, the properties are measured using the lab facility.

\section{Experimental Set-up and Methodology}

The experimental setup along with CRDI facility used in CI engine is shown in Figure 1. Diesel engine developing BP $5.2 \mathrm{~kW}$ was suitably modified with CRDI mode to operate with high injection pressure along with POME as alternative fuel biodiesel. The CRDI system has been established in house and controlled by electronic control unit (ECU) shown in Figure 2. ECU system makes easy to operate the CRDI diesel engine for biodiesel injections at different ITs and IOPs. The present experiments were carried out with variations in IT and IOP to optimize the CRDI diesel engine operation with POME. The experiments were conducted in the two parts, first part of experiment was carried by varying the IT from $25^{\circ} \mathrm{CA}$ bTDC to $5{ }^{\circ} \mathrm{CA}$ aTDC in interval of $5{ }^{\circ} \mathrm{CA}$. Finally, the fuel IT was optimized at $80 \%$ engine loading conditions. The engine speed, IOP were maintained constant at $1500 \mathrm{rpm}$ and 600 bar respectively by regulating speed and flow rate of pump in the CRDI engine. Optimized value of $10^{\circ} \mathrm{CAbTDC}$ IT was obtained. In the second experiment, IP was varied from 600bar to 1000 bar with 

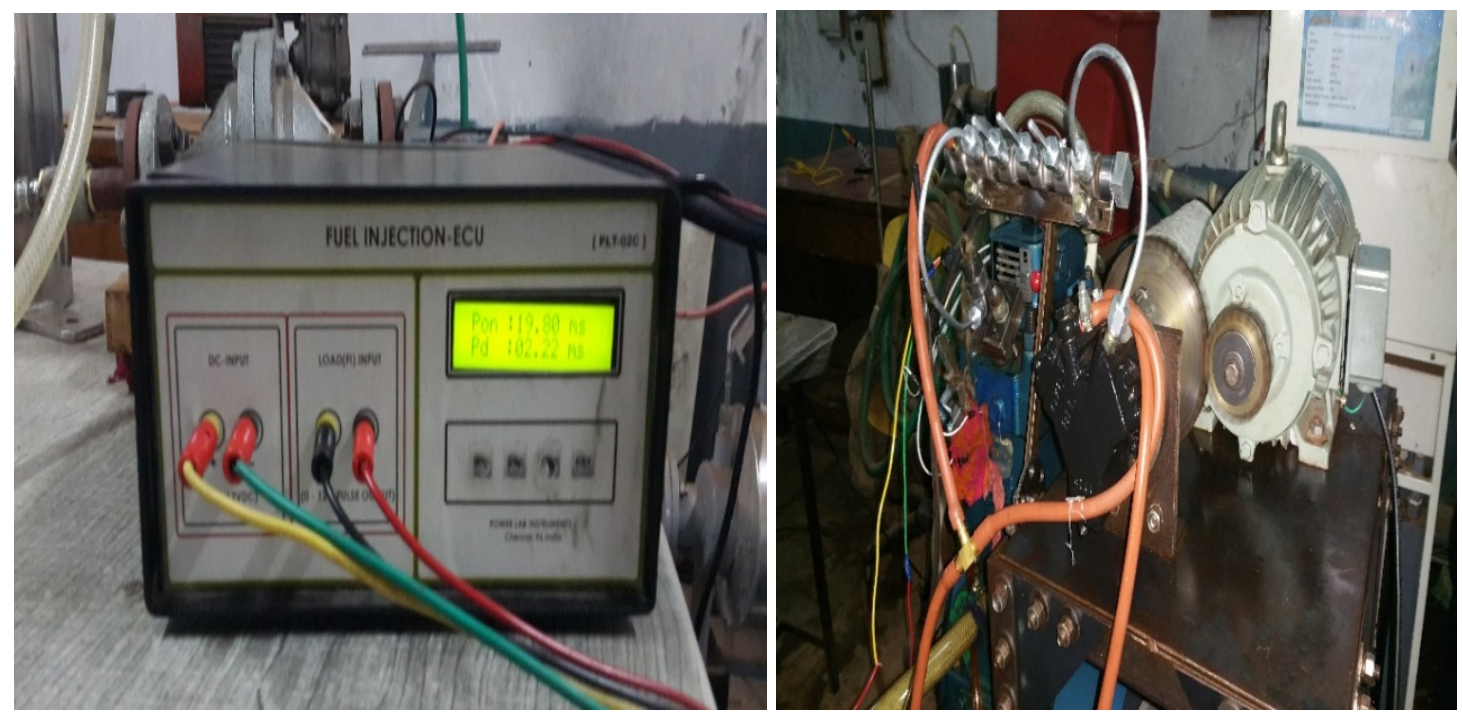

Figure 2. ECU connection with CRDI Engine Test Rig
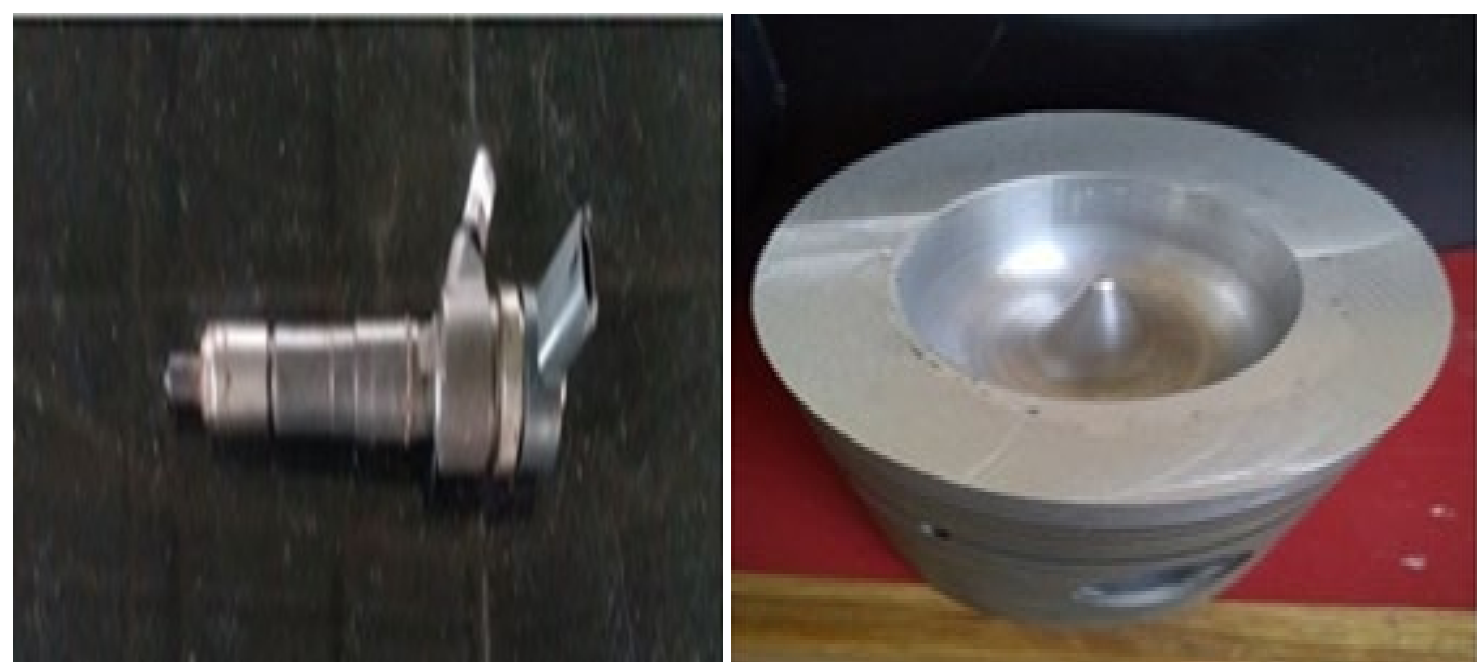

Figure 3. CRDI Injector (6 holes) and Toroidal Re-entrant Combustion Chamber Shape

constant IT in CRDI engine. The maximum 1000 bar pressure was attained in the system due to limitation of hardware capacity. ACRDI injector of6-hole nozzle injector with $0.2 \mathrm{~mm}$ diameter has been used for engine setup, TRCC shape combustion chamber was used to improve the mixing quality between POME and air were shown in Figure 3. Hence CRDI injector and modified combustion shape were potentially suitable for power output in $\mathrm{CI}$ engine. The important specification of experiment test rig showed in the Table 2. Cooling of engine was maintained by the supplying the water through the water jackets using pump. A piezoelectric transducer (Make: PCB Piezotronics, Model: HSM 111A22, Resolution: $0.145 \mathrm{mV} / \mathrm{kPa}$ ) was utilized for measurement of pressure, which was connected to cylinder head and specifications and connected to the cylinder head was utilized to measure the in-cylinder gas pressure. Figure 4 shows Hartridge smoke meter for smoke emission determination and five-gas analysers (A DELTA 1600 S-non-dispersive infrared analyzer) to measure $\mathrm{HC}, \mathrm{CO}, \mathrm{CO}_{2}, \mathrm{NOx}$ and $\mathrm{O}_{2}$ under steady state condition of engine operating conditions. Important specification of exhaust analyser and smoke meter are shown in Table 3. The TRCC shape of combustion chamber is developed by using CNC machines keeping the same CR between base line and modified shapes. The Optimum parameters of engine operated with POME were established based on the properties of fuel and results of experiments in engine.

\section{Uncertainty Analysis}

The uncertainties are most common in the measurement and parameter calculation, precise list of uncertainties calculated parameters are showed in the Table 4. 

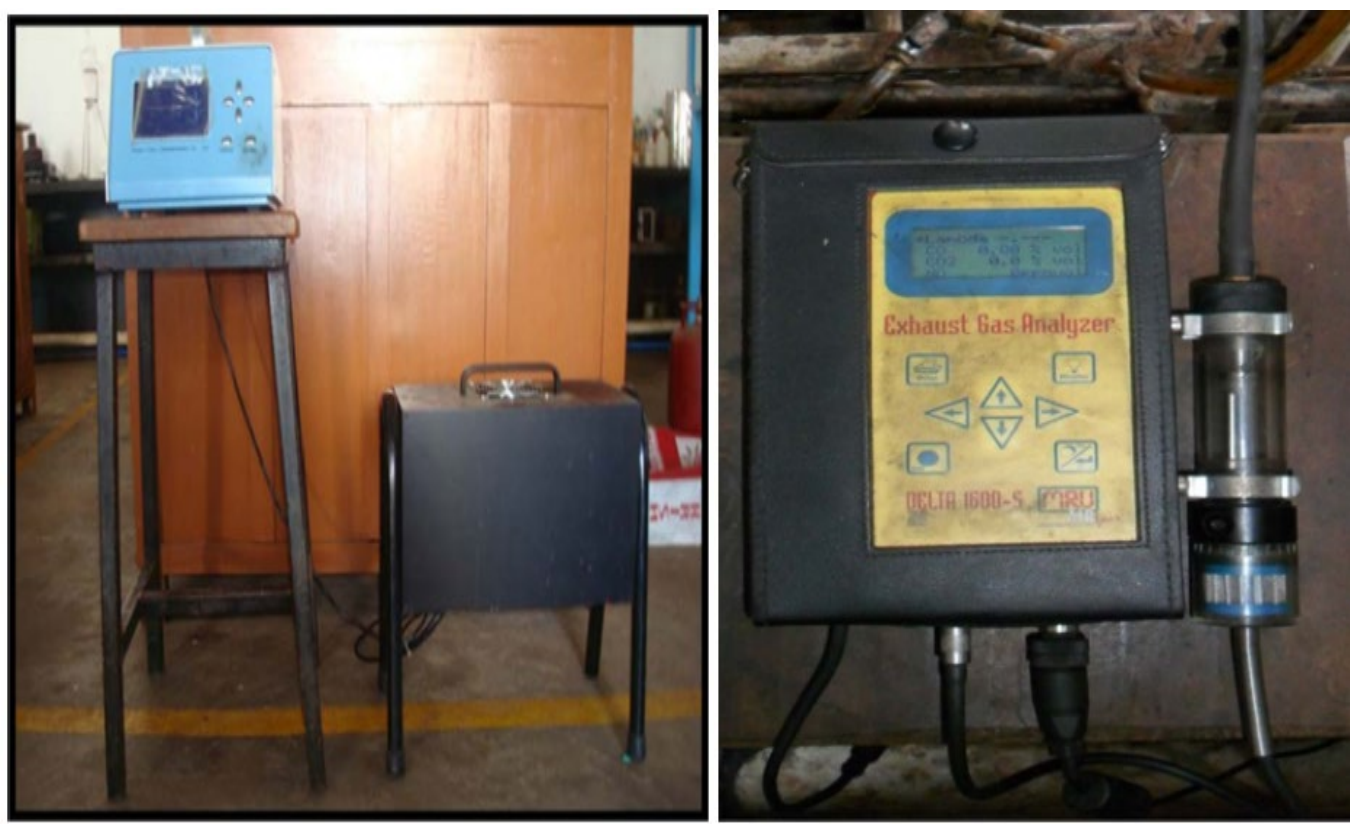

Figure 4. Exhaust Gas Analyzer and Smoke meter

Table 2. Specifications of the CI engine

\begin{tabular}{ll}
\hline Parameter & Specification \\
\hline Type & TV 1 (Kirlosker) \\
Software used & Engine soft \\
Nozzle opening pressure & $220-225$ bar \\
Governor type & Mechanical centrifugal type \\
Number of cylinder & Single cylinder \\
Number of stroke & Four stroke \\
Fuel & H.S. Diesel \\
Rated power & $5.2 \mathrm{~kW}(7 \mathrm{HP}$ at $1500 \mathrm{rpm})$ \\
Bore & $0.0875 \mathrm{~m}$ \\
Stroke length & $0.11 \mathrm{~m}$ \\
Compression ratio & $17.5: 1$ \\
\hline Air Measurement Manometer & \\
\hline Made & MX201 \\
Type & U-type \\
Range & $100-0-100 \mathrm{~mm}$ \\
\hline Eddy current Dynamometer & \\
Model & AG-10 \\
Type & Eddy current \\
Maximum & $7.5 \mathrm{~kW}$ (at $1500-3000$ RPM) \\
Flow & Water must flow through the dynamometer during the use \\
Dynamometer arm length & $0.180 \mathrm{~m}$ \\
Fuel measurement unit- range & $0-50$ ml \\
\hline
\end{tabular}

\section{RESULTS AND DISCUSSION}

\section{Optimization of Fuel IT for CRDI Diesel Engine}

The rigorous experiments have been performed on the CRDI diesel engine with diesel and POME fuels. The re-entrant combustion chamber chosen for experiment, 17.5: $1 \mathrm{CR}$ has kept constant; engine has made to run at constant speed $1500 \mathrm{rpm}$. The fuel IT has been optimized with varied fuel IT from $25^{\circ} \mathrm{CAbTDC}$ to $5{ }^{\circ} \mathrm{CA}$ aTDC with steps of $5{ }^{\circ} \mathrm{CA}$ for $80 \%$ and $100 \%$ engine load condition. The IOP 600 bar is kept constant in CRDI engine for all the fuel IT of engine with 6 holes $0.2 \mathrm{~mm}$ diameter CRDI injector. For the study $80 \%$ and $100 \%$ engine were selected and discussed results of performance, combustion and emission characteristics.

\section{IT Effect on BTE}

The effect of injection timing with BP at 80\% and 100\% loads operating with POME and diesel fuels in CRDI engine shown in Figure 5. As per obtained results depicted that maximum BTE showed at $10^{\circ} \mathrm{bTDC}$ for POME biodiesel. The maximum BTE of POME fuel at $10^{\circ} \mathrm{bTDC}$ due to the improved atomization of POME at 600 bar. The better mixing strength is also one of the reasons to improved BTE. The wall wetting has been reduced leads 
Table 3. The specifications of exhaust gas analyzer and smoke meter

\begin{tabular}{|c|c|c|c|}
\hline Type & DELTA 1600S & Type & HARTRIDGE Smokemeter-4 \\
\hline Object of Measurement & $\begin{array}{l}\text { Carbon monoxide }(\mathrm{CO}) \text {, Carbon dioxide }\left(\mathrm{CO}_{2}\right) \text {, Oxides } \\
\text { nitrogen }\left(\mathrm{NO}_{\mathrm{x}}\right) \text { and Hydrocarbons }(\mathrm{HC})\end{array}$ & $\begin{array}{l}\text { 6丹bject of } \\
\text { measurement }\end{array}$ & Smoke \\
\hline \multirow[t]{4}{*}{ Range of measurement } & $\begin{array}{l}\mathrm{HC}=0 \text { to } 20,000 \mathrm{ppm} \text { as } \mathrm{C} 3 \mathrm{H} 8 \text { (propane) } \\
\mathrm{CO}=0 \text { to } 10 \%\end{array}$ & $\begin{array}{l}\text { Measurement range } \\
\text { opacity }\end{array}$ & $0-100 \%$ \\
\hline & $\mathrm{CO}_{2}=0$ to $16 \%$ & Accuracy & $+/-\%$ relative \\
\hline & $\mathrm{O}_{2}=0$ to $21 \%$ & Resolution & $0.1 \%$ \\
\hline & $\mathrm{NO}_{\mathrm{x}}=0$ to $5,000 \mathrm{ppm}$ (as Nitric oxide) & Smoke length & $0.43 \mathrm{~m}$ \\
\hline \multirow[t]{3}{*}{ Accuracy } & $\begin{array}{l}\mathrm{HC}=+/-30 \mathrm{ppm} \mathrm{HC} \\
\mathrm{CO}=+/-0.2 \% \mathrm{CO}\end{array}$ & $\begin{array}{l}\text { Ambient } \\
\text { temperature }\end{array}$ & $-5^{\circ} \mathrm{C}$ to $+45^{\circ} \mathrm{C}$ \\
\hline & $\begin{array}{l}\mathrm{CO}_{2}=+/-1 \% \mathrm{CO} 2 \\
\mathrm{O}_{2}=+/-0.2 \% \mathrm{O} 2\end{array}$ & Warm up time & $\begin{array}{l}10 \text { minutes (self-controlled) at } \\
20^{\circ} \mathrm{C}\end{array}$ \\
\hline & $\mathrm{NO}_{\mathrm{x}}=+/-10 \mathrm{ppm} \mathrm{NO}$ & Speed of response & Within 15 seconds for $90 \%$ \\
\hline \multirow[t]{4}{*}{ Resolution } & $\mathrm{HC}=1 \mathrm{ppm}$ & time & response \\
\hline & $\mathrm{CO}=0.01 \%$ Vol. & Sampling & Directly sampled from tail pipe \\
\hline & $\begin{array}{l}\mathrm{CO}_{2}=0.1 \% \text { Vol. } \\
\mathrm{O}_{2}=0.01 \% \mathrm{Vol}\end{array}$ & Power supply & $\begin{array}{l}100 \text { to } 240 \text { V AC/50 HZ } \\
10 \text { to } 16 \text { V DC @ } 15 \text { amps }\end{array}$ \\
\hline & $\mathrm{NO}_{\mathrm{x}}=1 \mathrm{ppm}$ & Size & $100 \mathrm{~mm}$ X $210 \mathrm{~mm}$ X $50 \mathrm{~mm}$ \\
\hline Warm up time & 10 minutes (self-controlled) at $20^{\circ} \mathrm{C}$ & & \\
\hline Speed of response time & Within 15 seconds for $90 \%$ response & & \\
\hline Weight & $800 \mathrm{gm}$ & & \\
\hline
\end{tabular}

Table 4. The uncertainties in the calculated parameters

\begin{tabular}{ll}
\hline Measure variable & Accuracy $( \pm)$ \\
\hline Load & 0.1 \\
\hline Engine speed $(\mathrm{rpm})$ & 1 \\
\hline Temperature $\left({ }^{\circ} \mathrm{C}\right)$ & 1 \\
\hline Fuel consumption $(\mathrm{g})$ & 0.1 \\
\hline Measured variable & Uncertainty $(\%)$ \\
\hline $\mathrm{HC}$ & \pm 1.2 \\
\hline $\mathrm{CO}$ & \pm 2.5 \\
\hline $\mathrm{NO}$ & \pm 2.3 \\
\hline Smoke & \pm 2.0 \\
\hline Calculated parameter & Uncertainty $(\%)$ \\
\hline BTE $(\%)$ & \pm 1.2 \\
\hline HRR $\left(\mathrm{J} /{ }^{\circ} \mathrm{CA}\right)$ & \pm 1.3 \\
\hline
\end{tabular}
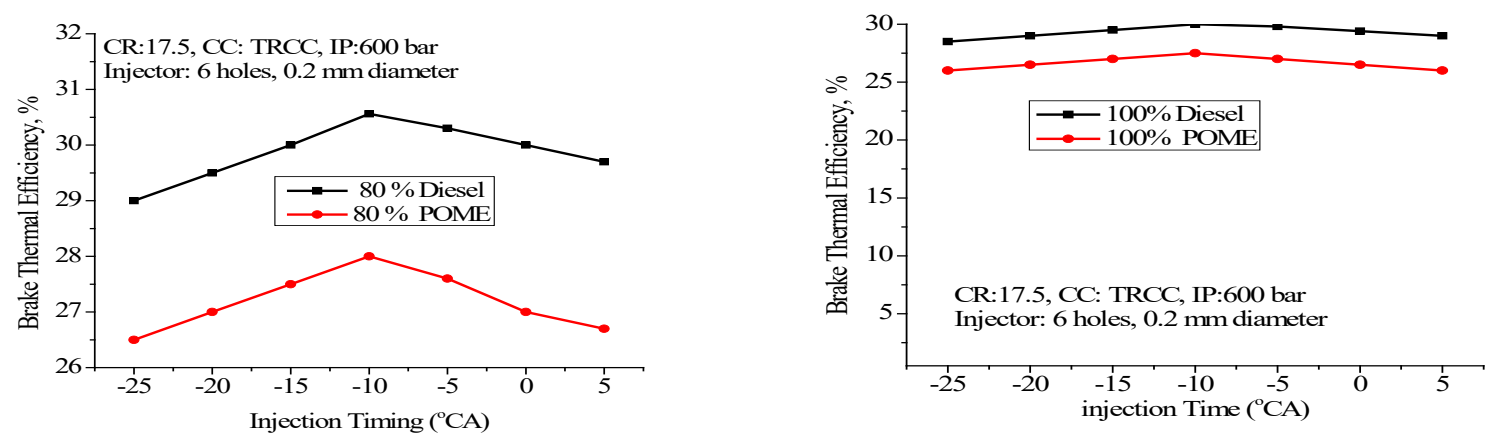

Figure 5. Effect of fuel IT on BTE for POME and Diesel fuels at $80 \%$ load and 100\% load

to improved burning rate of fuel leads to improve the BTE of the engine operated with POME. The CRDI engine was affecting in its efficiency by retarding or advancing the fuel IT. By retardation of IT, reduced BTE due to more amount of fuel entered in to crevice leads to decrease in available time for mixing fuel-air. On other hand, by advancing the fuel IT leads to reduced BTE due to increased wall wetting at higher IOP. At 80\% load, BTE were $28,30.56 \%$ for POME and diesel respectively at $10^{\circ}$ bTDC IT. Similarly, at $100 \%$ load, $27.5,30 \%$ for POME and diesel respectively at $10^{\circ} \mathrm{bTDC}$ IT. By results higher BTE obtained for diesel compared to POME due to higher calorific and lower viscosity of mineral diesel fuel at $10^{\circ} \mathrm{bTDC}$ IT and 80\% load under engine conditions 6-hole CRDI injector, TRCC shape with 600 bar IOP in CRDI engine. For 100\% load slightly BTE has been reduced due to negating effect in the engine.

\section{IT Effect on Smoke Opacity}

From Figure 6 illustrates that the effect of injection timing with smoke opacity at 80\% and 100\% loads operating with POME and diesel fuels in CRDI engine. Smoke level of diesel has lower as compared to POME in 

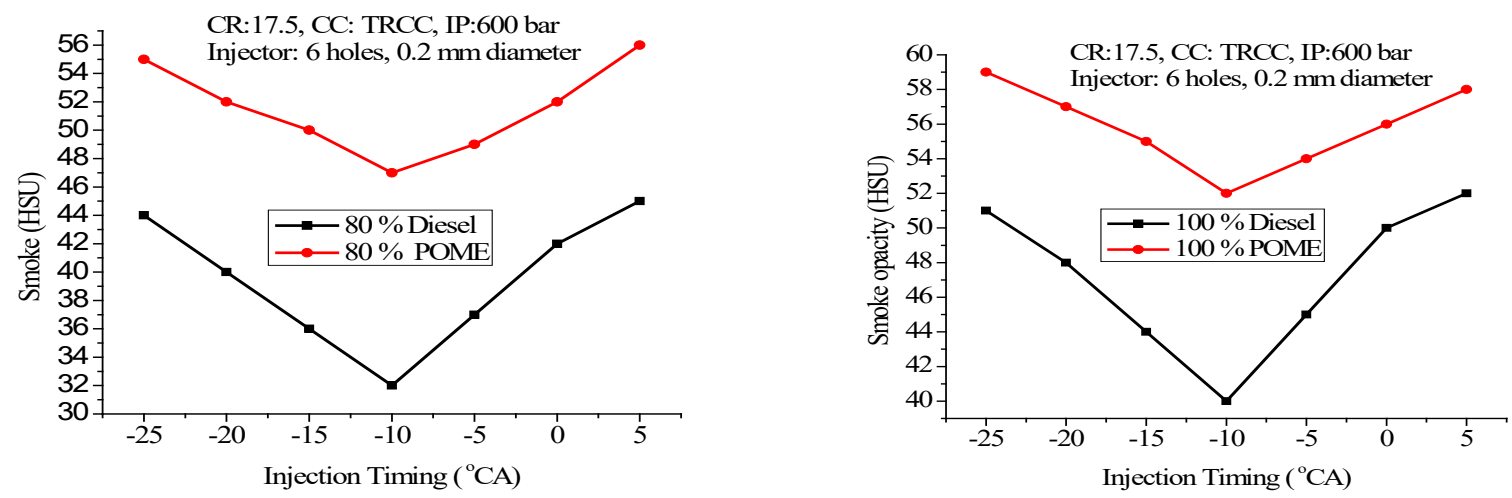

Figure 6. Effect of fuel IT on smoke for POME and Diesel fuels at $80 \%$ load and $100 \%$ load
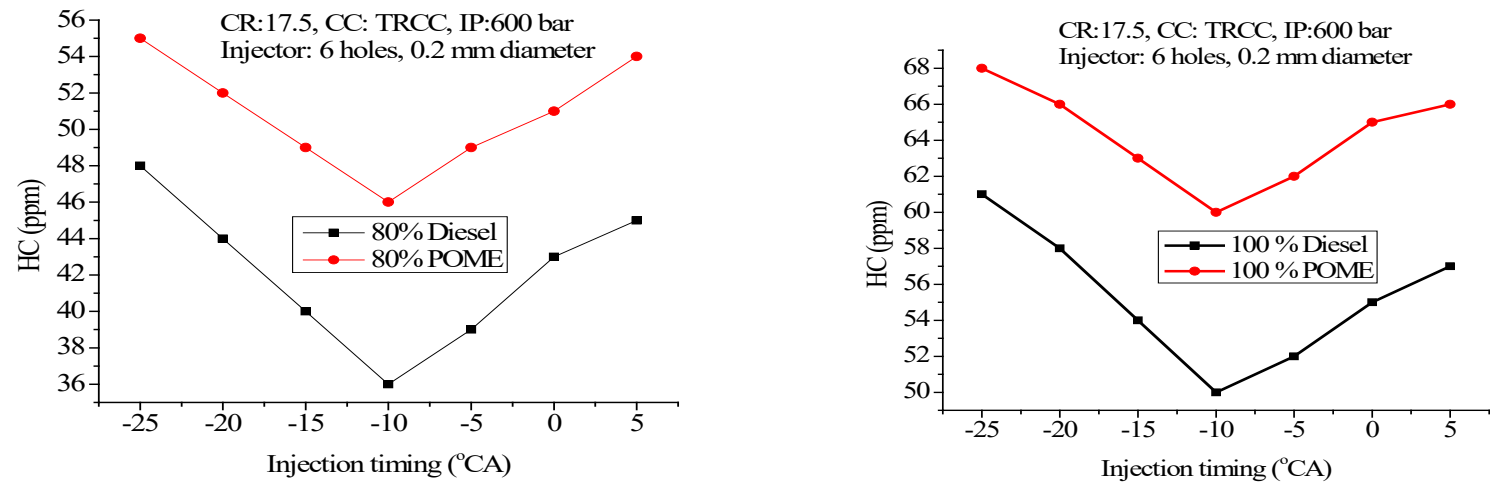

Figure 7. Effect of fuel IT on HC for POME and Diesel fuels at $80 \%$ load and $100 \%$ load

the CRDI engine due to the heavier presence of FFA in the POME. The higher viscous nature of the POME leads to loose the mixing quality in the combustion chamber. The smoke level of both fuels has been showed decreasing trend up to $10{ }^{\circ} \mathrm{bTDC}$ at $600 \mathrm{bar}$ due to wall wetting was reduced. Hence, combustion process of both fuels was improved for higher BTE and formation of oxidation reactions in the combustion chamber. But beyond $10^{\circ} \mathrm{bTDC}$ increasing in the smoke intensity was observed due to the rate of mixing of air and fuel quality has been reduced leads to slow combustion rate formation. However, smoke intensity of POME higher than the diesel fuel in CRDI engine due to higher viscosity. The results formed for smoke levels were 47, $32 \mathrm{HSU}$ for POME and diesel respectively at $80 \%$ load and $10^{\circ}$ bTDC. Similarly, for $100 \%$ load obtained results were $66,40 \mathrm{HSU}$ for POME and diesel respectively at $10^{\circ} \mathrm{bTDC}$. However, smoke intensity of POME higher than the diesel fuel in CRDI engine due to poor mixing characteristics at $10^{\circ}$ bTDC under engine conditions of $80 \%$ load, 6-hole CRDI injector, TRCC shape with 600 bar IP in CRDI engine.

\section{IT Effect on $H C$ and CO Emissions}

From Figures 7 and 8 depicted that the effect of fuel IT with HC, CO emissions for POME and diesel at 80\%, $100 \%$ loads for CRDI engine. The POME fuel operated CRDI engine resulted higher HC and CO emissions than diesel fuel due to poor quality of air fuel mixture. The presence of heavier molecular structure in POME fuel leads to bigger size of fuel particles, hence poor combustion of POME could be the reason to higher emissions at 600 bar. The emissions like HC, CO were out by engine minimum at $10^{\circ} \mathrm{bTDC}$ IT due to improved combustion of fuel droplet size at constant 600 bar and higher BTE occurred. However, CO and HC emissions were higher for other fuel IT due to improper combustion. The advanced fuel IT behind the $10^{\circ} \mathrm{bTDC}$ leads to increase in wall wetting of combustion chamber, by retarding the fuel IT beyond the $10^{\circ} \mathrm{bTDC}$ leads to more amount fuel injecting in to crevice that is loss of power in the engine. HC emissions obtained at $80 \%$ load were $46,36 \mathrm{ppm}$ for POME and diesel fuels respectively for CRDI mode at $10^{\circ} \mathrm{bTDC}$. Similarly, at 100\% load 60, $50 \mathrm{ppm}$ for POME and diesel fuels respectively for CRDI mode at $10{ }^{\circ}$ bTDC. CO emissions obtained at $80 \%$ load were $0.16,0.13 \%$ for POME and diesel fuels respectively for CRDI mode at $10^{\circ} \mathrm{bTDC}$. Similarly, at $100 \%$ load $0.22,0.18 \%$ for POME and diesel fuels respectively for CRDI mode at $10^{\circ} \mathrm{bTDC}$. However, the HC and CO pollutants were optimized at $10^{\circ} \mathrm{bTDC}$ IT for POME and diesel fuels under the engine conditions of $600 \mathrm{bar}$, 6-hole CRDI injector with TRCC shape. 

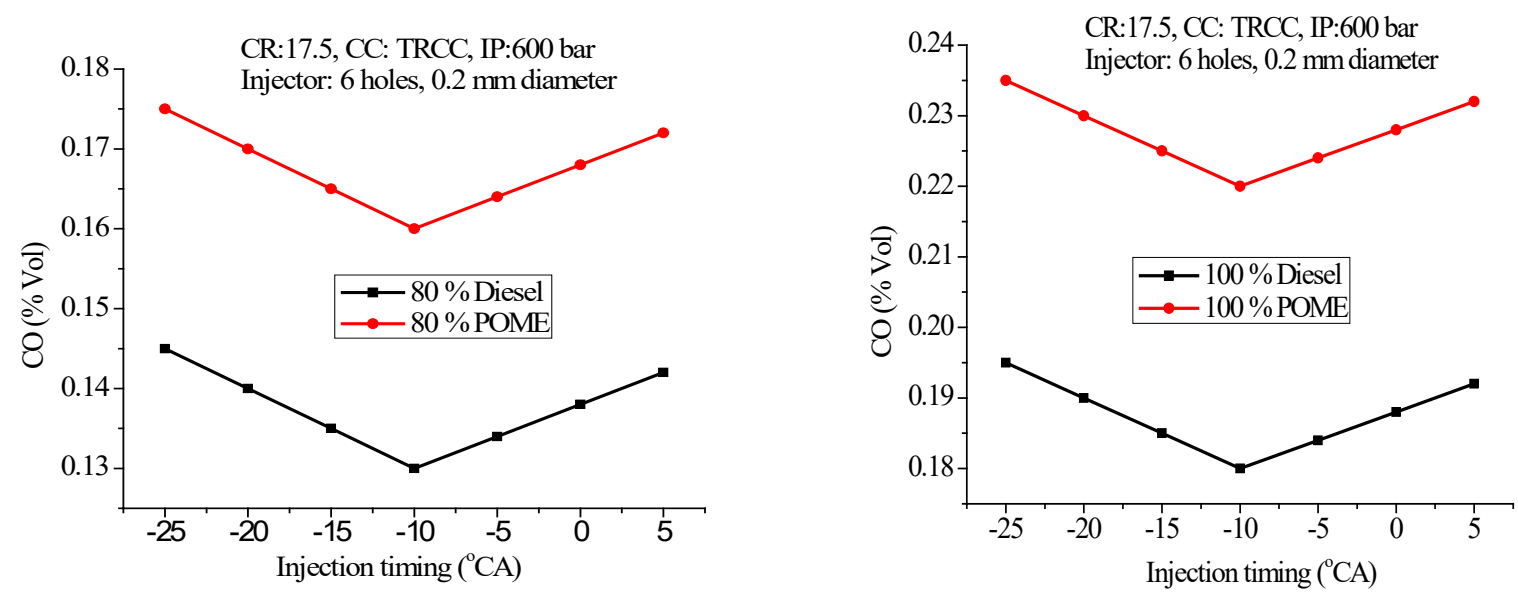

Figure 8. Effect of fuel IT on CO for POME and Diesel fuels at 80\% load and 100\% load
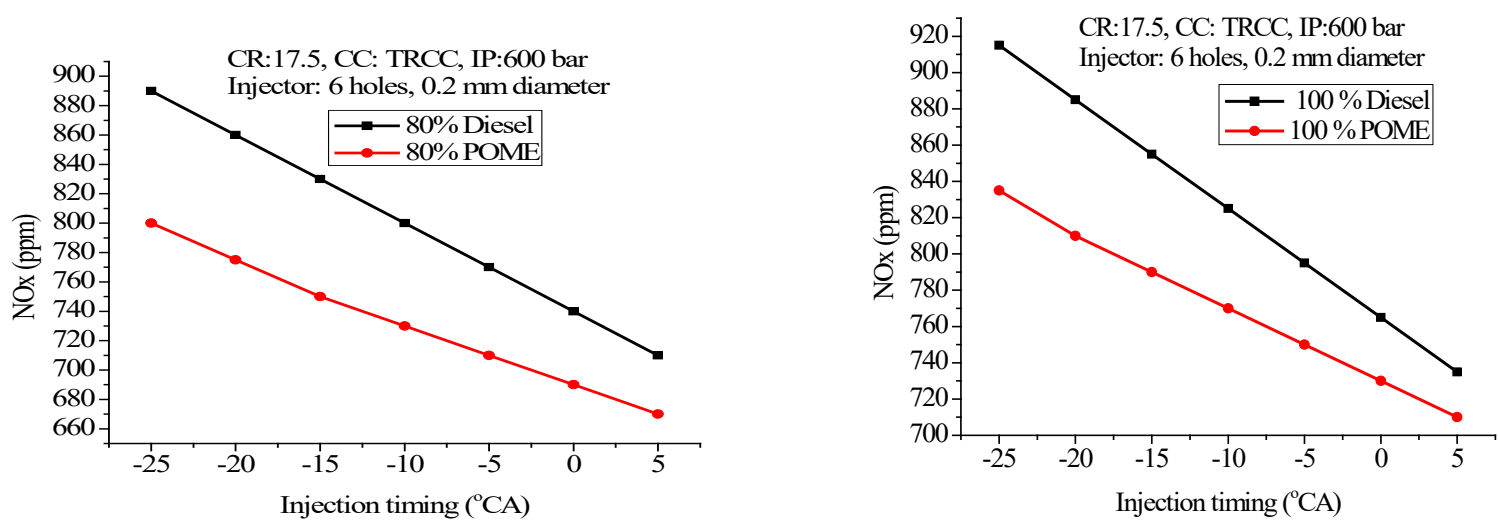

Figure 9. Effect of fuel IT on NOx for POME and Diesel fuels at $80 \%$ load and 100\% load

\section{IT Effect on NOx Emissions}

Figure 9 revealed that the variation of fuel IT with NOx at $80 \%$ and $100 \%$ loads for POME and diesel fuels in CRDI engine. Peak Pressure and Heat release rate were increased in both cases of loads and fuels due to presence of longer ID. Hence, there was enhanced nature in NOx emissions at advanced fuel IT behind of $10^{\circ} \mathrm{bTDC}$. This peak NOx emission was obtained due to higher exhaust peak temperature occurred in the cylinder. In both loads, decreasing trend of NOx emission was observed for retarded IT in CRDI mode. The NOx emission obtained at $80 \%$ load were 730, $800 \mathrm{ppm}$ for POME and diesel respectively at fuel IT of $10^{\circ}$ bTDC. Similarly, at $100 \%$ load 770, $825 \mathrm{ppm}$ for POME and diesel respectively at fuel IT of $10^{\circ} \mathrm{bTDC}$. However, minimized NOx emissions has been observed for POME fuel compared to diesel fuel due to lower cetane number leads to decreased in gas temperature at $10^{\circ} \mathrm{bTDC}, 80 \%$ load, 600 bar IP and 6-hole CRDI injector in CRDI diesel.

\section{IT Effect on Ignition Delay}

Figure 10 depicted that the variation of ID with crank angle for POME and diesel at 80\%, 100\% loads in CRDI engine. In both cases of loads, ID was decreasing trend up to $10^{\circ} \mathrm{bTDC}$ IT, then it increased further due to higher gas temperature. However, the POME showed higher ID as compared to diesel fuel due to lower cetane number of POME fuel for both loading conditions of CRDI engines at $10^{\circ} \mathrm{bTDC}$ IT, $600 \mathrm{bar}$. This result could be the heavier molecular structure of POME leads slow combustion rate in the combustion chamber. At $80 \%$ load ID results were $14.01,13.4^{\circ} \mathrm{CA}$ for POME and diesel fuels respectively at $10{ }^{\circ} \mathrm{bTDC}$ IT. Similarly, at $100 \%$ load $13.72,13.12^{\circ} \mathrm{CA}$ for POME and diesel fuels respectively at $10^{\circ} \mathrm{bTDC}$ IT. The $80 \%$ load of ID has been optimized with CRDI mode, 6-hole CRDI injector, 600 bar, $10^{\circ} \mathrm{bTDC}$ and TRCC shape due to higher BTE.

\section{IT Effect on Combustion Duration}

The variation of combustion duration with crank angle for POME and diesel fuels at $80 \%, 100 \%$ loads in CRDI diesel engine illustrated in Figure 11. As retarding the fuel IT, CD was tends to deceases up to $10^{\circ} \mathrm{bTDCIT}$, further again increased CD was observed for both the fuels with $80 \%$ and $100 \%$ loads. This is due to higher gas 

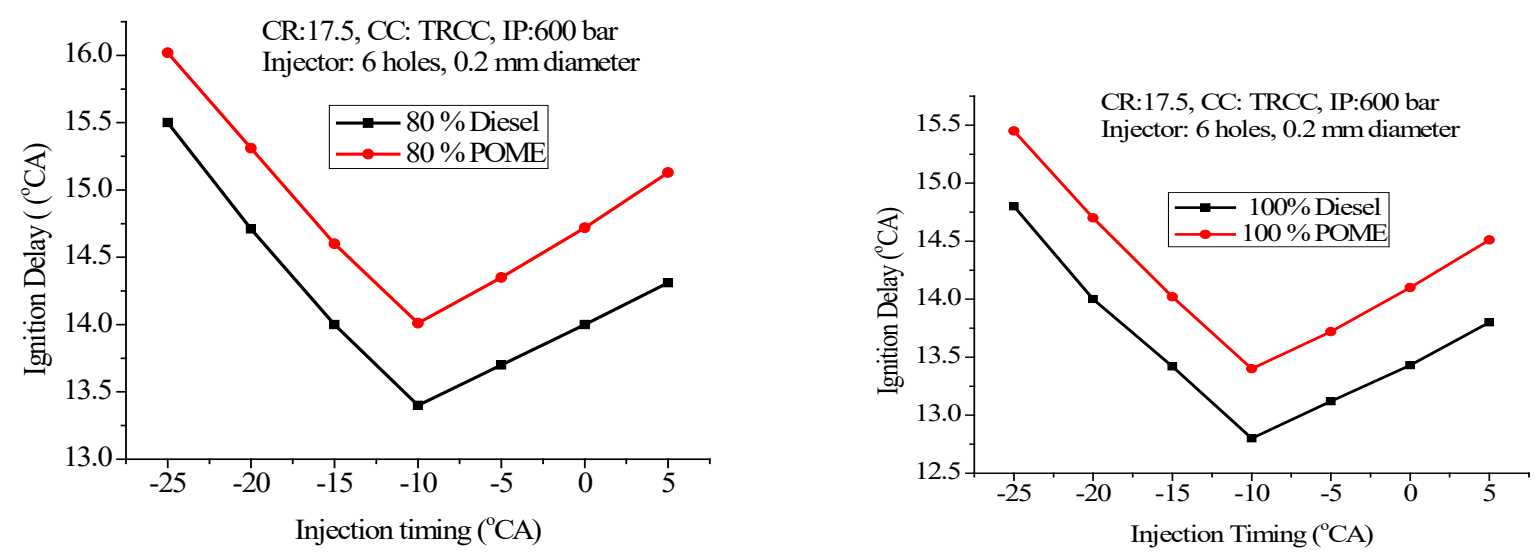

Figure 10. Effect of fuel IT on NOx for POME and Diesel fuels at $80 \%$ load and $100 \%$ load
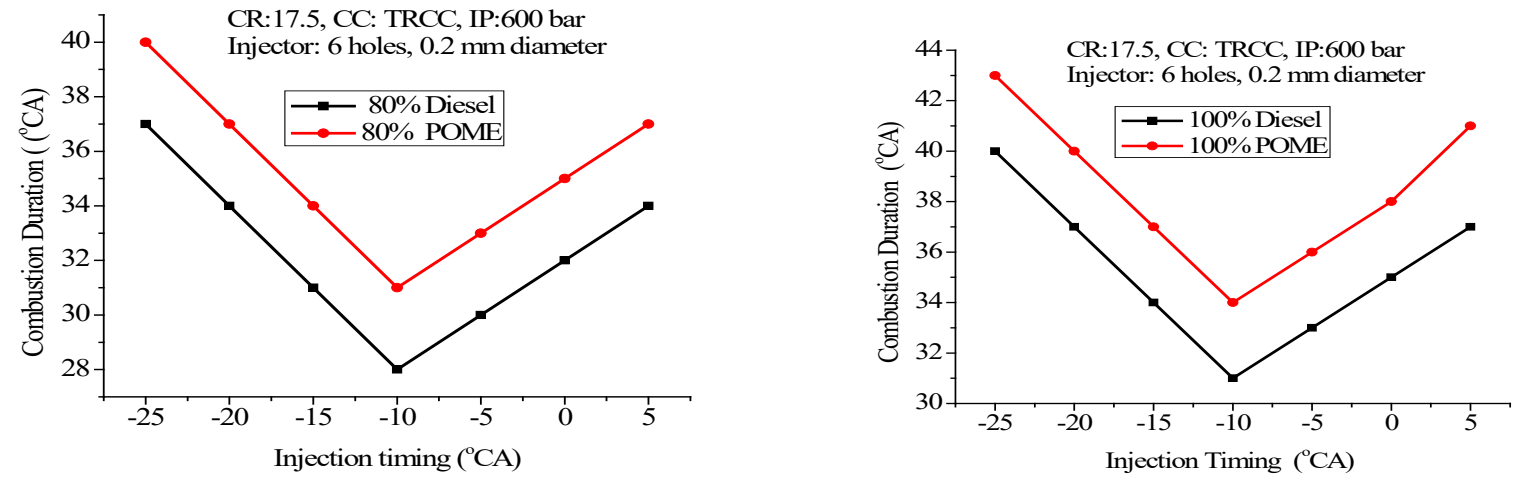

Figure 11. Effect of fuel IT on CD for POME and Diesel fuels at 80\% load and 100\% load

temperature generated in the combustion chamber up to $10^{\circ} \mathrm{bTDC}$ IT. Further rise of temperature is decreases by retardation of fuel IT due to lower low burning rate of fuel may be reason. CD obtained at $80 \%$ load were 31 , $28{ }^{\circ} \mathrm{CA}$ for POME and diesel fuels respectively at $10{ }^{\circ} \mathrm{bTDC}$ IT. Similarly at $100 \%$ load $34,31^{\circ} \mathrm{CA}$ for POME and diesel fuels respectively at $10{ }^{\circ} \mathrm{bTDC}$ IT. However, POME exhibited higher CD compared to diesel due to lower energy content and higher viscosity are could be the reason at $10^{\circ} \mathrm{bTDC}$ IT, 600 bar, 6 hole CRDI injector and TRCC shape for $80 \%$ load in CRDI engine.

\section{IT Effect on Peak Pressure}

From Figure 12 depicted that the variation of Peak Pressure with crank angle for POME and diesel fuels at 80\%, 100\% loads in CRDI diesel engine. In both the loads, POME and diesel fuels of peak pressure were decreasing trend as retarding the fuel IT due to reduced ID period in CRDI engine. In contrast of advancing the fuel IT, higher peak pressure was observed due to more available fuel quantity during chemical reaction in diffused combustion stage. The results of Peak Pressure were 72, 74 bar obtained for POME and diesel fuels respectively with at $10{ }^{\circ} \mathrm{bTDC}$ with $80 \%$ load. Similarly, 75, 79 bar for POME and diesel respectively at $10{ }^{\circ} \mathrm{bTDC}$ with $100 \%$ load. However, POME fuel has been observed lower peak pressure than diesel fuel due to lower calorific of POME fuel. This leads to reduced mixing quality of fuel and air $\mathrm{r}$ in the combustion chamber at $10^{\circ} \mathrm{bTDC}$ IT, $600 \mathrm{bar}, 6$ hole CRDI injector and TRCC shape for $80 \%$ load in CRDI engine.

\section{IT Effect on Heat Release Rate}

Variation of HRR with crank angle for POME and diesel fuels at 80\%, 100\% loads in CRDI diesel engine illustrated in Figure 13. In both the loads of engine condition, Heat release rate of POME and diesel fuels were higher at advanced fuel IT due to maximum availability of fuel. Hence, it enhances the chemical reactions in the diffused combustion zone of combustion process. The drop of HRR was observed for both fuels in CRDI engine due to more quantity of fuel wall wetting leads to reduced burning rate of fuel during retarding the IT. The results of $\mathrm{HRR}$ were $65,70 \mathrm{~J} /{ }^{\circ} \mathrm{CA}$ obtained for POME and diesel respectively with at $10^{\circ} \mathrm{bTDC}$ with $80 \%$ load. Similarly, $82,88 \mathrm{~J} /{ }^{\circ} \mathrm{CA}$ for POME and diesel fuels respectively at $10{ }^{\circ} \mathrm{bTDC}$ with at $100 \%$ load. However, POME exhibited the lower HRR than diesel due to lower energy content of fuel could be the reason. The $80 \%$ load of HRR has 

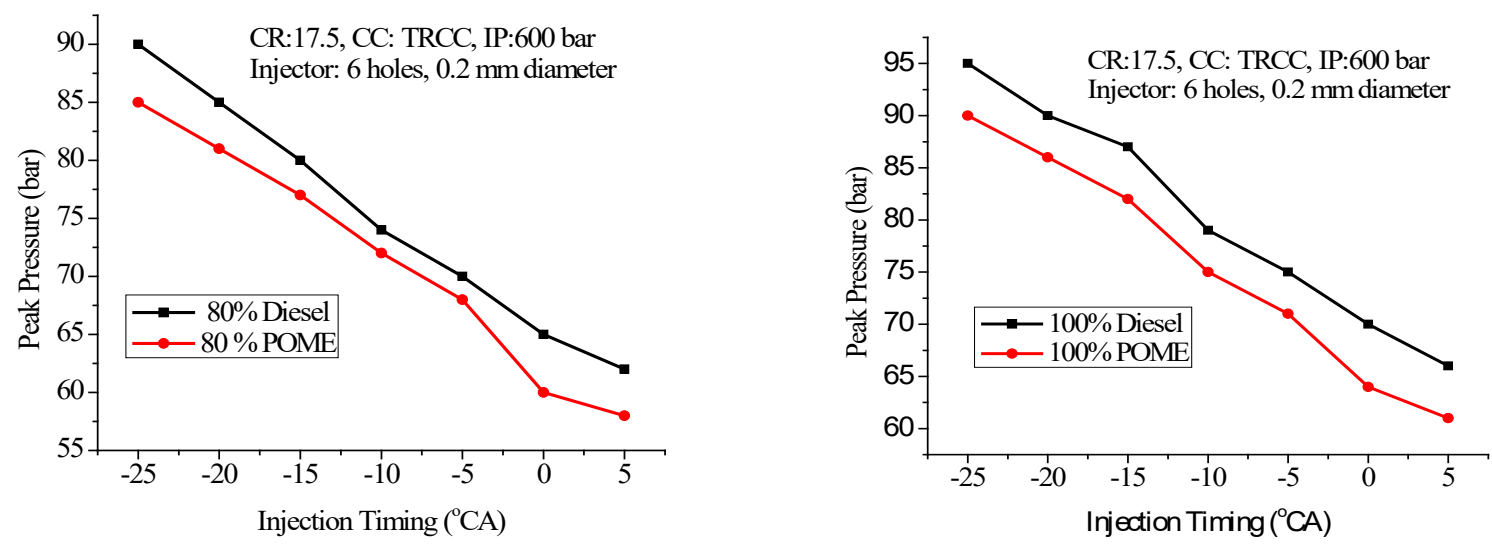

Figure 12. Effect of fuel IT on PP for POME and Diesel fuels at $80 \%$ load and $100 \%$ load
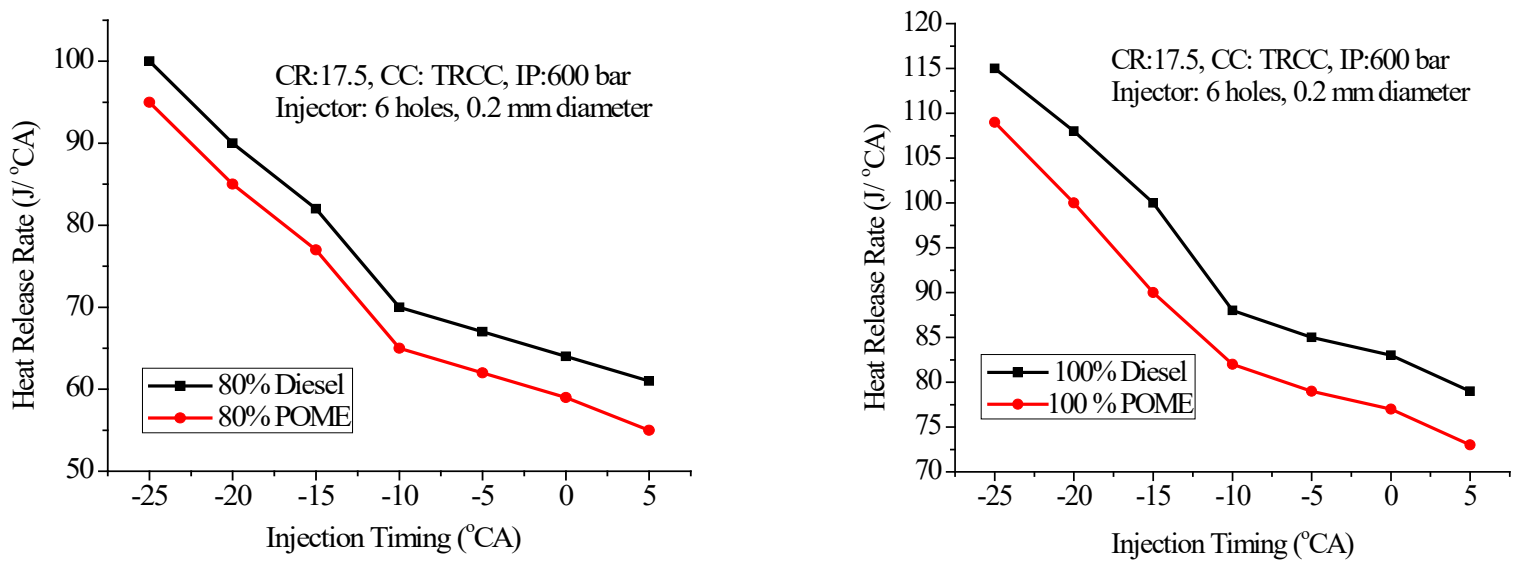

Figure 13. Effect of fuel IT on HRR for POME and Diesel fuels at $80 \%$ load and $100 \%$ load

been optimized for POME with CRDI mode, 6 hole CRDI injector, $600 \mathrm{bar}, 10^{\circ} \mathrm{bTDC}$ and TRCC shape due to higher BTE.

\section{Optimization of IOP for the Diesel and POME Fuels in CRDI Engine}

With reference to first part of experiment results of research work, the $80 \%$ load and $10^{\circ}$ bTDCIT were optimized for higher BTE and minimized emissions for the CRDI engine powered with POME and diesel fuels under the engine conditions of 6-hole CRDI injector, constant 600 bar IOP and TRCC shape. However, the variation IOP was influencing very significantly on CRDI engine performance operating with alternative fuels. Hence for current studied, IOP varied from 600 to 1000 bar in the interval of 100 bar for POME and diesel fuels with optimized fuel IT constant at $10^{\circ} \mathrm{CA}$ bTDC. The engine speed was maintained at $1500 \mathrm{rpm}$. For the study, $80 \&$ and 100\% load were selected along with 6 holes (0.2 mm diameter) CRDI injector and TRCC shape were chosen.

\section{IOP effect on BTE}

From Figure 14 illustrated that effect of IOP on BTE operated with diesel and POME fuels in CRDI engine at $80 \%$ load and $100 \%$ load. The BTE has been increased up to $900 \mathrm{bar}$ IOP and later reduction of BTE trend was observed for both fuels due to negating effect of engine. The atomization spray characteristics have been improved by increasing the IOP from 600 bar to 900 bar. This leads to formation of homogeneous mixture in the combustion chamber and reduced ignition delay at higher pressure could be the reason to raised BTE. The viscosity of fuel is to reduce at higher pressure of fuel injection. The reduced viscous fuel easily mixes with air and fuel leads to improve the combustion process in the combustion chamber. The BTE of engine has been decreased at 1000 bar IOP due to more fuel wall wetting. However, BTE has higher at IOP 900 bar due to higher fuel penetration of fuel and increased fuel dispersion in the combustion chamber. Thermal efficiency of diesel value has more compare to POME at 900 bar due to presence of lower cetane number, higher FFA and lower volatility. The HRR of POME has lesser than the base line fuel (diesel) under same conditions of engine. The results of BTE obtained at $80 \%$ load and 900 bar were $28.75,32 \%$ for POME and diesel respectively. Similarly, at 100\% load and 900 bar 

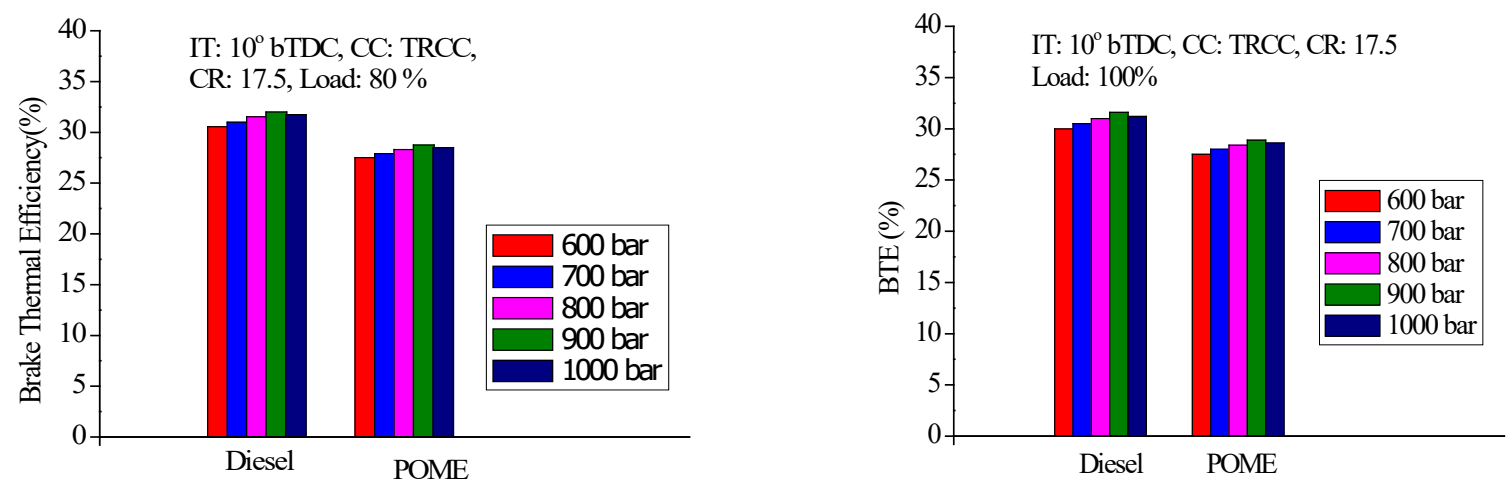

Figure 14. Effect of BTE on IOP for POME and Diesel fuels at 80\% load and 100\% load
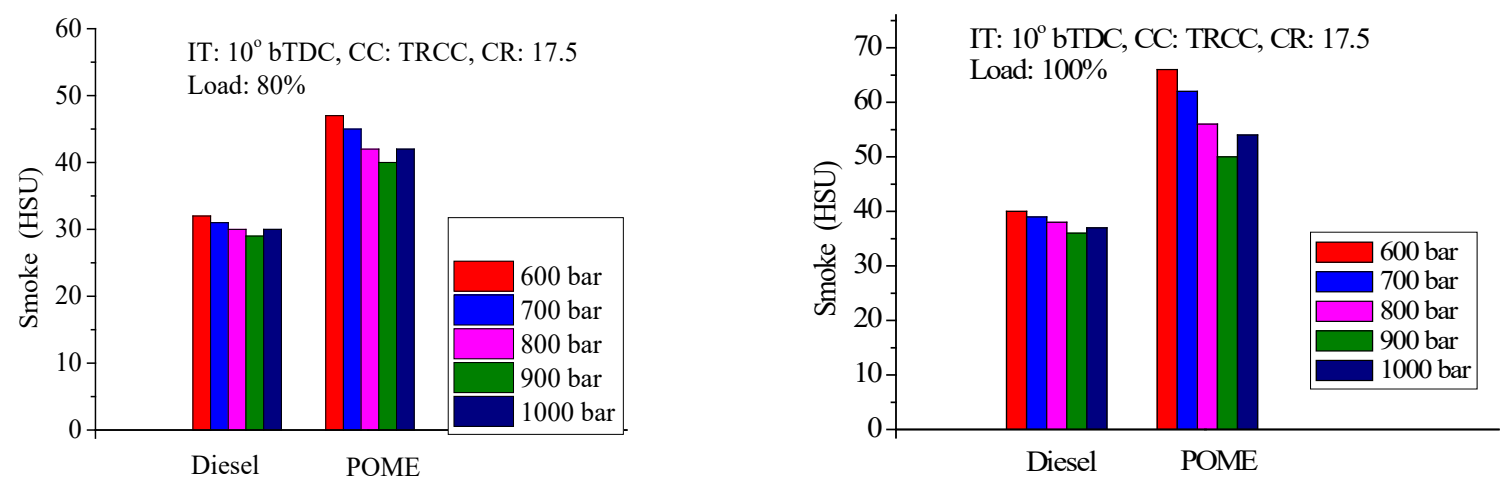

Figure 15. Effect of smoke level on IOP for POME and Diesel fuels at $80 \%$ load and 100\% load

28.6, 31.6\% for POME and diesel respectively. Finally, POME resulted higher BTE at 80\% load with CRDI mode at the engine conditions of 900 bar, $10^{\circ}$ bTDC, TRCC shape and 6 holes CRDI injector.

\subsubsection{Effect of IOP on Smoke Level}

Figure 15 showed that the effect IOP on BTE with smoke level in CRDI engine for POME and diesel at 80\% and 100\% load. The POME fuel has been resulted greater smoke level than diesel due to presence of both higher weighted molecular structure and viscosity. The POME exhibited unsuitable air-fuel mixture in the combustion chamber leads to increased smoke emissions for POME than base line fossil fuel. The POME fuel showed reduced emissions up to 900 bar IOP due to better atomization of fuel particles leads to enhanced combustion process in the combustion chamber. The smoke level results were 29, $40 \mathrm{HSU}$ for diesel and POME at 900 bar and $80 \%$ load. Similarly, for 100\% load 36 and 50 HSU for diesel and POME respectively at 900 bar. By comparison of both loads, $80 \%$ load was optimized for lower smoke level under engine conditions of $900 \mathrm{bar}, 10{ }^{\circ} \mathrm{bTDC}$, TRCC shape and 6 holes CRDI injector for CRDI diesel engine.

\section{Effect of IOP on $H C$ and $C O$ emissions}

The Figures 16 and 17 depicted that the variation of IOP on HC, CO emissions for POME and diesel fuels at $80 \%$ load and 100\% load of CRDI engine. Usually for higher IOP, decreasing trend of CO and HC emissions have been observed for both fuels and loads. This result could be a reason for better atomization and enhancing complete combustion rate of injection fuel in the combustion chamber. Due to presence of higher oxygen content and proper burning rate in POME leads to decreased trend of emissions (HC and CO) at 900 bar IOP. But the emissions slightly higher for POME compare to mineral diesel in CRDI diesel engine due to higher viscosity could be the reason. The HC and CO emissions out from engine were higher for 1000bar due to increased wall wetting phenomenon and also the fuel spray emerging in larger distance in CC could be the reason for both fuels and loads at higher pressure. HC emissions were 37 and 30ppm for POME and diesel respectively at $80 \%$ load and 900 bar IP. Similarly, for 100\% load, 53 and 44ppm for POME and diesel fuels respectively at 900 bar IP. CO emissions obtained were 0.145 and $0.12 \%$ for POME and diesel fuels respectively at $80 \%$ load respectively and 900 bar IP. Similarly at $100 \%$ load 0.205 and $0.171 \%$ for POME and diesel fuels respectively at 900 bar IP. By the results, $80 \%$ 

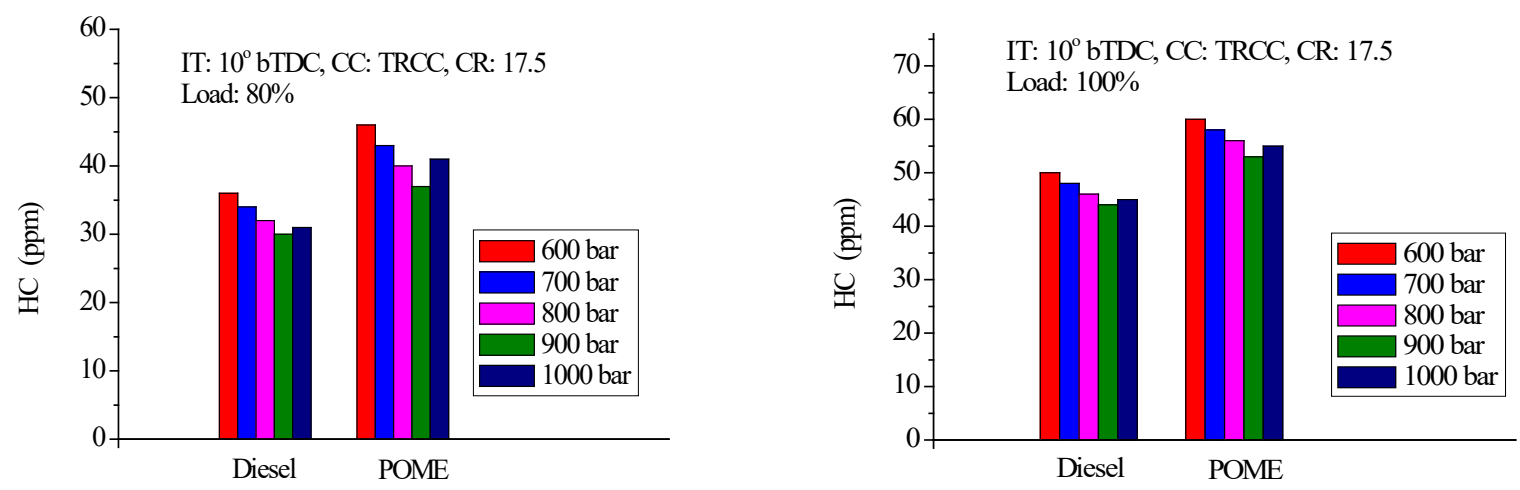

Figure 16. Effect of HC on IOP for POME and Diesel fuels at 80\% load and 100\% load
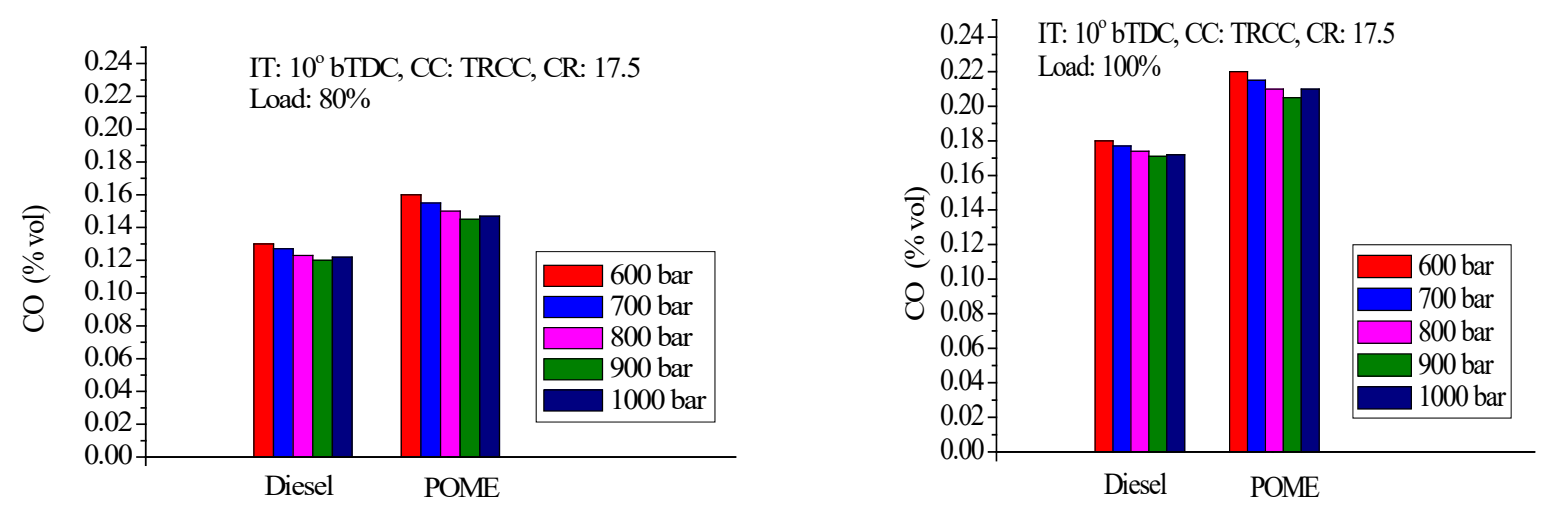

Figure 17. Effect of CO on IOP for POME and Diesel fuels at $80 \%$ load and $100 \%$ load

load was optimized for lower HC and CO emissions under engine conditions of $900 \mathrm{bar}, 10{ }^{\circ} \mathrm{bTDC}$, TRCC shape and 6 hole CRDI injector for CRDI diesel engine.

\section{Effect of IOP on NOx Emissions}

From the Figure 18 revealed that the variation of IOP on $\mathrm{NO}_{\mathrm{x}}$ emissions for POME and diesel fuels at $80 \%$ load and 100\% load of CRDI engine. Due to improved atomization and dispersion characteristics of fuel leads to enhanced combustion rate. Hence gas temperature increased in the cylinder at higher injection pressure of fuel. Diesel fuel depicted that higher NOx emission from engine compared to POME fuel due to POME has lower viscosity and higher density value. There are two factors affecting for the better mixing strength of air and fuel mixture. These factors were dispersion fuel quality and smaller size of fuel droplets led to decreased in ID. Hence HRR has been more in quantity at higher operating pressure of IP (900 bar), that enhances the higher gas temperature with formation more $\mathrm{NO}_{\mathrm{x}}$ out from engine. By the observed results depicted that, $\mathrm{NO}_{\mathrm{x}}$ out from engine with respect to POME fuel could be lower emissions due to premixed combustion phase stage was lower as compared to fossil diesel fuel. The arising the lower adiabatic flame temperature in the combustion chamber and lower $\mathrm{CN}$ of POME were reasons to lower $\mathrm{NO}_{\mathrm{x}}$ emission from engine. The $\mathrm{NO}_{\mathrm{x}}$ emissions obtained were 784 and $850 \mathrm{ppm}$ for POME and diesel fuels respectively at 80\% load and 900 bar IP. Similarly, at 100\% load 814 and 875 ppm for POME and diesel respectively at 900 bar IP. Form the results observed that, the $80 \%$ load was showed the higher $\mathrm{NO}_{\mathrm{x}}$ for CRDI diesel engine under engine conditions of $900 \mathrm{bar}, 10^{\circ} \mathrm{bTDC}$, TRCC shape and 6 holes CRDI injector.

\section{Effect of IOP on Ignition Delay}

From the Figure 19 illustrated that the variation of ID with IOP for POME and diesel fuels at $80 \%$ and 100\% load in CRDI engine. The reduced ID was observed by increasing the injection pressure for both the loads due to better burning rate of fuels. The increased ID was observed beyond the 900 bar IP due to higher wall wetting led to lower mixture quality. Because of higher BTE consideration for $80 \%$ load, the results for ID were $10.3,9.6{ }^{\circ} \mathrm{CA}$ for POME and diesel respectively at 900 bar IP. Similarly for $100 \%$ load, 10.92, $10.2{ }^{\circ} \mathrm{CA}$ for POME and diesel respectively at 900 bar IP. However, lower ID for diesel as compare to POME was observed in both loads at 

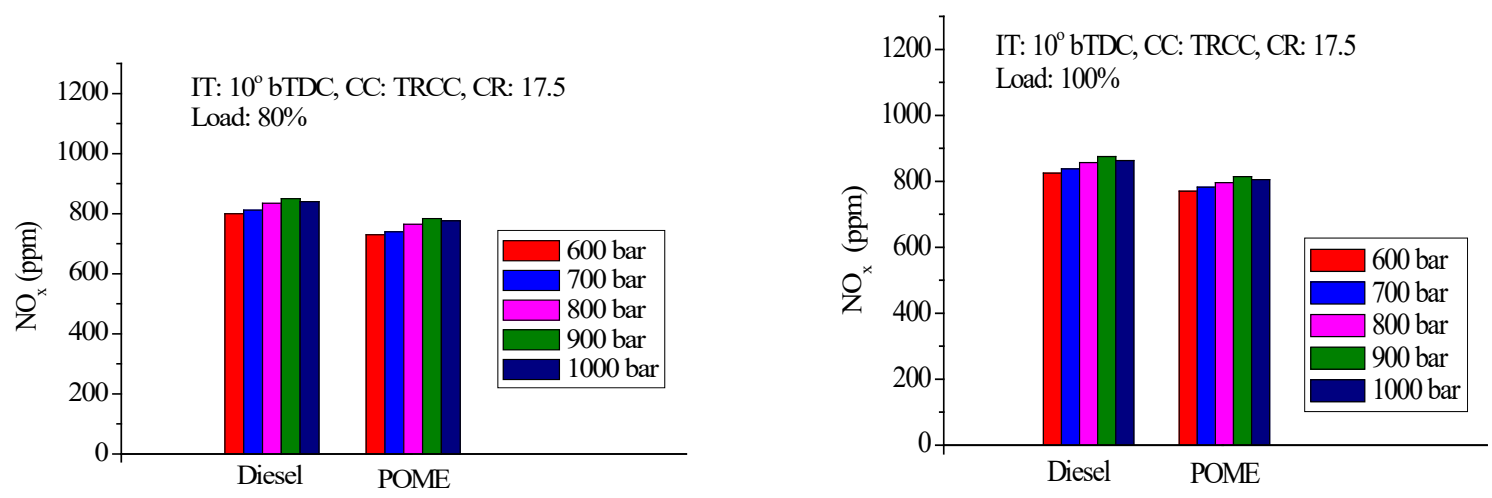

Figure 18. Effect of NOx on IOP for POME and Diesel fuels at $80 \%$ load and $100 \%$ load
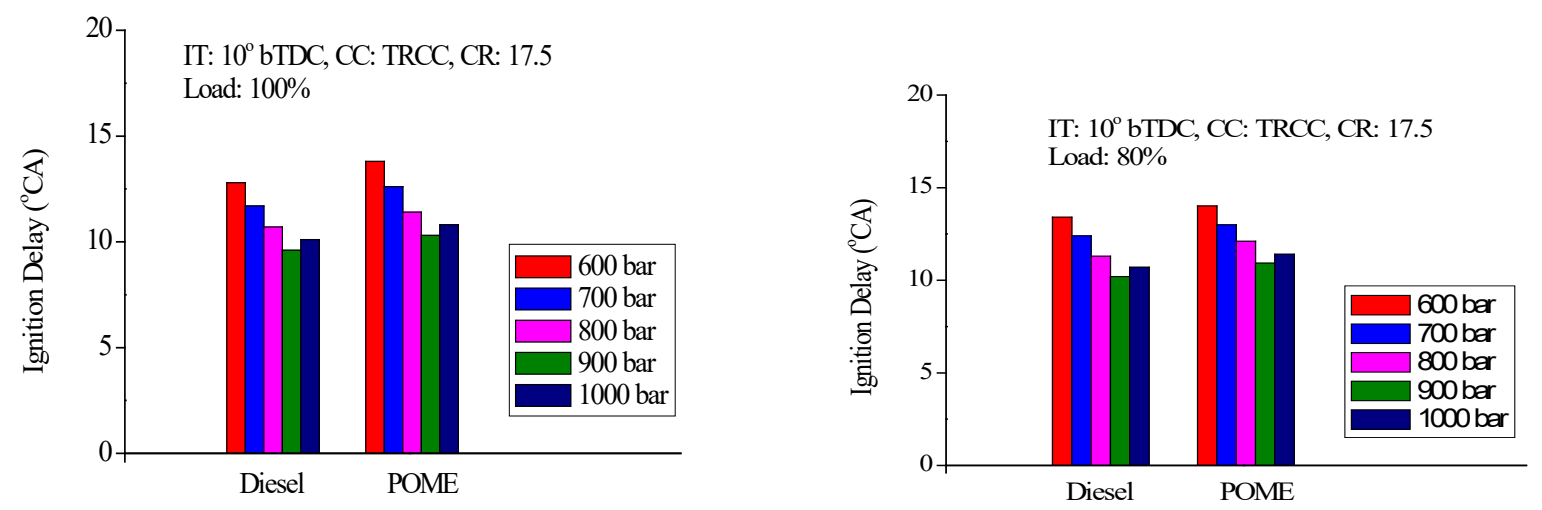

Figure 19. Effect of ID on varied IOP for POME and Diesel fuels at $80 \%$ load and $100 \%$ load
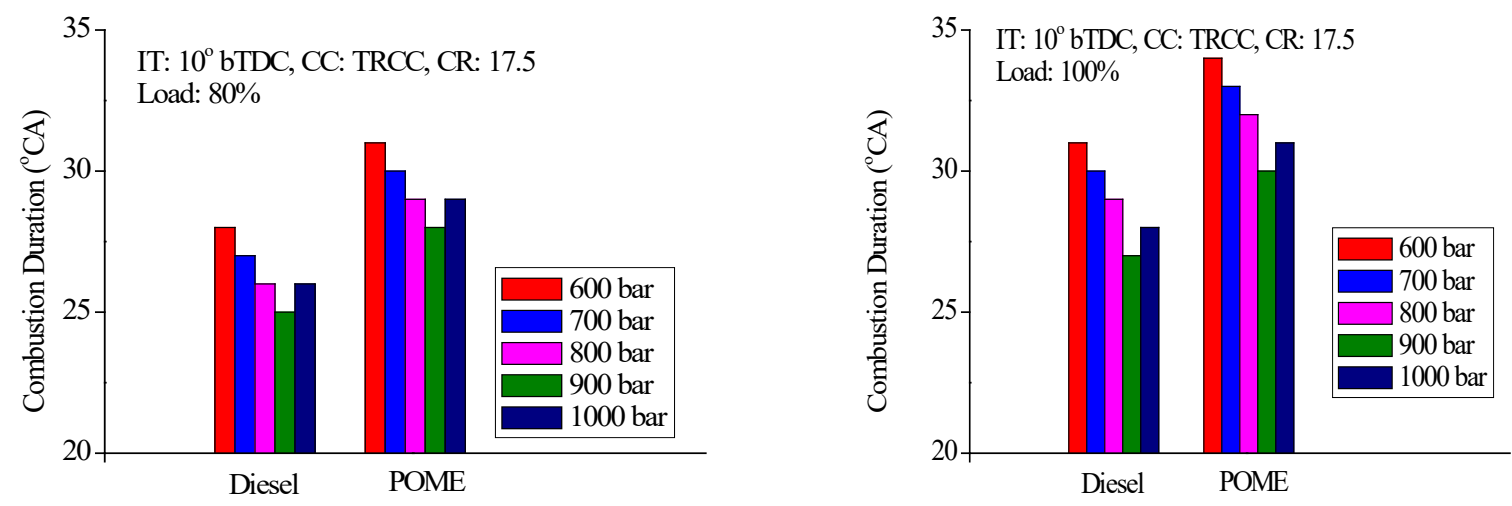

Figure 20. Effect of CD on varied IOP for POME and Diesel fuels at $80 \%$ load and $100 \%$ load

higher IOP due to higher energy content in mineral diesel fuel under engine conditions of $900 \mathrm{bar}, 10^{\circ} \mathrm{bTDC}$, TRCC shape and 6 hole CRDI injector for CRDI diesel engine.

\section{Effect of IOP on Combustion Duration}

From the Figure 20 depicted that the variation of CD with IOP for POME and diesel fuels at $80 \%$ and $100 \%$ load in CRDI engine. The fuel droplet size has been reduced by increasing the injection pressure due better atomization of fuel. Hence CD was decreased trend up to $900 \mathrm{bar}$ for both the loads due to better burning rate of fuels. The increased CD was observed beyond the 900 bar IP due to higher wall wetting led to lower mixture strength quality. The consideration of higher BTE at $80 \%$ load, the results for $\mathrm{CD}$ were $28,25^{\circ} \mathrm{CA}$, for POME and diesel respectively at 900 bar IP. Similarly, for $100 \%$ load, 30 and $27^{\circ} \mathrm{CA}$ for POME and diesel respectively at 900 bar IP. However, lower CD for diesel as compare to POME was observed in both loads at higher IOP due 

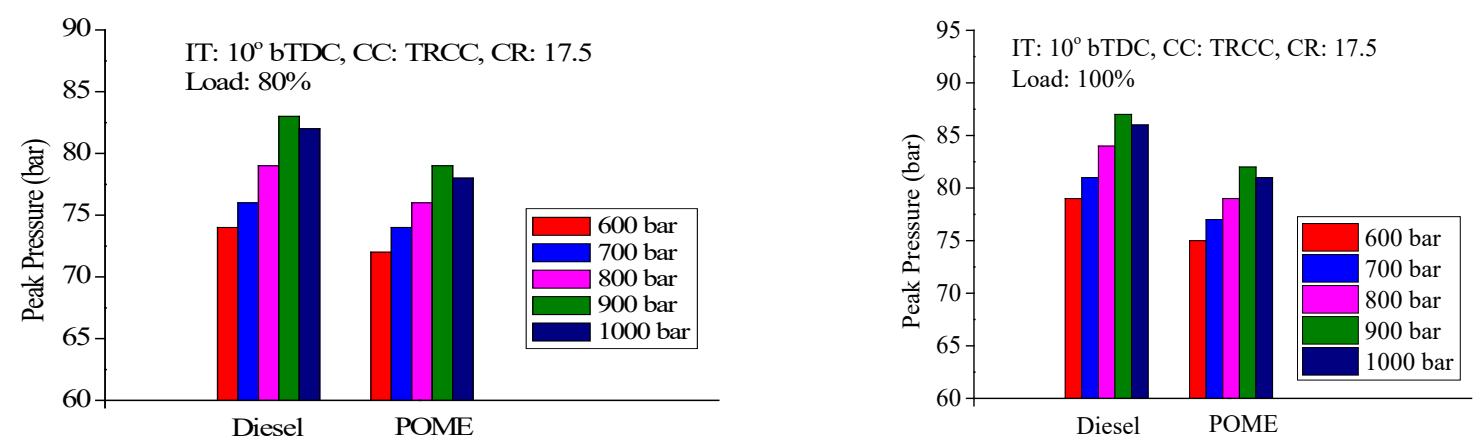

Figure 21. Effect of PP on varied IOP for POME and Diesel fuels at $80 \%$ load and $100 \%$ load
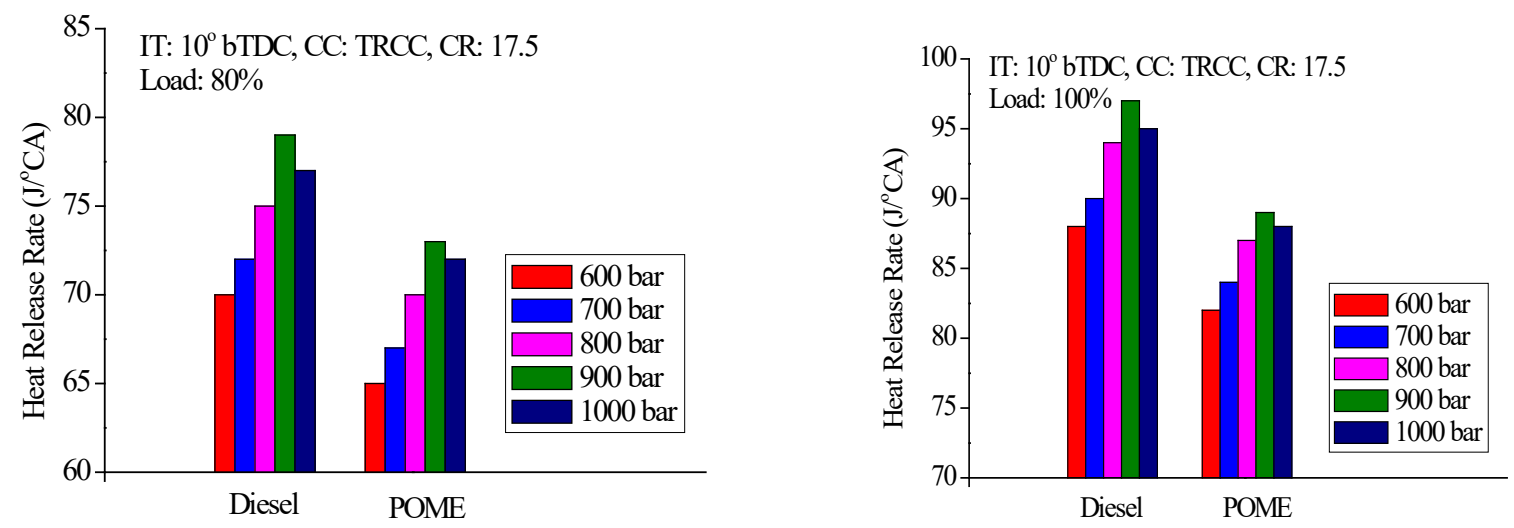

Figure 22. Effect of HRR on varied IOP for POME and Diesel fuels at $80 \%$ load and 100\% load

to lower viscosity in mineral diesel fuel under engine conditions of $900 \mathrm{bar}, 10{ }^{\circ} \mathrm{bTDC}$, TRCC shape and 6-hole CRDI injector for CRDI diesel engine.

\section{Effect of IOP on Peak Pressure}

From the Figure 21 depicted that the variation of peak pressure with IOP for POME and diesel fuels at $80 \%$ and 100\% load in CRDI engine. The peak pressure was raised up to 900 bar IP due to better fuel atomization and reduced ID are could be the reasons. The Peak Pressure was shown decreased trend beyond 900 bar due to more quantity of fuel entered in the crevices leads to inadequate combustion process in the combustion chamber. For $80 \%$ load, the results for PP were 79, 83 bar, for POME and diesel respectively at 900 bar IP. Similarly, for 100\% load, 82, 87 bar for POME and diesel respectively at 900 bar IP. However, higher PP for diesel as compare to POME was observed in both loads at 900 bar IP due to lower viscosity in mineral diesel fuel under engine conditions of $900 \mathrm{bar}, 10^{\circ} \mathrm{bTDC}$, TRCC shape and 6 holes CRDI injector for CRDI diesel engine.

\section{Effect of IOP on Heat Release Rate}

From the Figure 22 illustrated that the variation of HRR with IOP for POME and diesel fuels at 80\%, 100\% load in CRDI engine. The heat release rate was raised until 900 bar IP by enhancing the CRDI nozzle injector pressure due to better fuel atomization. The reduced ID was the reason to raise the heat release rate at higher injection pressure. The HRR was shown decreased trend by further increasing in pressure due to more quantity of fuel entered in the crevices leads to inadequate combustion process in the combustion chamber. For $80 \%$ load, the results for $\mathrm{HRR}$ were $73,79 \mathrm{~J} /{ }^{\circ} \mathrm{CA}$, for POME and diesel respectively at $900 \mathrm{bar}$ IP. Similarly, for $100 \%$ load, 89 and $97 \mathrm{~J} /{ }^{\circ} \mathrm{CA}$ for POME and diesel respectively at $900 \mathrm{bar}$ IP. However, higher HRR for diesel fuel as compare to POME fuel was observed in both loads at 900 bar IP. This due to POME has higher viscous than diesel led to more friction formed in the injector needle. Hence, there was hinders in valve lifting movement leads to longer ID in POME operation. So reduced HRR was obtained in the engine under conditions of $900 \mathrm{bar}, 10^{\circ} \mathrm{bTDC}$, TRCC shape and 6 holes CRDI injector for CRDI diesel engine. 


\section{CONCLUSIONS}

From entire exhaustive experimental work conducted for POME and diesel fuels for $80 \%$ and $100 \%$ load in CRDI diesel engine. The $80 \%$ engine load was optimized for higher efficiency of engine. Hence the following conclusions were made for $80 \%$ engine load only:

- When CRDI diesel engine operated with POME has resulted maximum BTE under following the engine conditions were $10^{\circ} \mathrm{bTDC}$ fuel IT, constant IP 600 bar, 6 holes CRDI nozzle geometry and $17.5 \mathrm{CR}$ with TRCC shape.

- When CRDI diesel engine operated with POME at optimized $10^{\circ} \mathrm{bTDC}$ fuel IT, BTE was increased and reduced emissions for $900 \mathrm{bar}$ IP as compared to other IP with 6 holes CRDI injector, TRCC shape for constant CR.

- On overall, CRDI diesel engine operated with POME as alternative fuel resulted higher BTE and lower emissions under engine conditions of 900 bar IP, $10^{\circ} \mathrm{bTDC}$ fuel IT, TRCC shape and 6 holes CRDI injector with CR constant 17.5. By using POME as alternative fuel for $\mathrm{CI}$ engine with slight modification of engine helps to resolve all possible problems were raised from fossil fuel throughout world.

\section{NOMENCLATURE}

$\begin{array}{ll}\text { HCC } & \text { Hemispherical Combustion Chamber } \\ \text { TRCC } & \text { Torroidal reentrant combustion chamber shape } \\ \text { UBHC } & \text { Unburnt Hydro Carbon } \\ \text { NO }_{x} & \text { Oxides of Nitrogen } \\ \text { CO } & \text { Carbon Monoxide } \\ \text { BP } & \text { Brake Power in KW } \\ \text { SFC } & \text { Specific Fuel Consumption in Kg/KW-hr } \\ \text { CR } & \text { Compression Ratio } \\ \text { POME } & \text { Palm oil Methyl Ester } \\ \text { CRDI } & \text { Common Rail Direct Injection } \\ \text { IOP/IP } & \text { Injection Opening Pressure } \\ \text { IT } & \text { Injection Timing } \\ \text { bTDC } & \text { Bottom Top Dead Centre } \\ \text { BDF } & \text { Biodiesel Fuel } \\ \text { ECU } & \text { Electronic Control Unit } \\ \text { CD } & \text { Combustion Duration } \\ \text { PP } & \text { Peak Pressure } \\ \text { HRR } & \text { Heat Release Rate } \\ \text { ID } & \text { Ignition Delay }\end{array}$

\section{REFERENCES}

Aalam, C. S., Saravanan, C. G. and Anand, B. P. (2016). Impact of high fuel injection pressure on the characteristics of CRDI diesel engine powered by mahua methyl ester blend. Applied Thermal Engineering, 106, 702-711. https://doi.org/10.1016/j.applthermaleng.2016.05.176

Aalam, C. S. and Saravanan, C. G. (2017). Effects of nano metal oxide blended Mahua biodiesel on CRDI diesel engine. Ain Shams Engineering Journal, 8, 689-696. https:/ /doi.org/10.1016/j.asej.2015.09.013

Agarwal, A. K., Dhar, A., Gupta, J. G., Kim, W. I., Choi, K., Lee, C. S. and Park, S. (2015). Effect of fuel injection pressure and injection timing of Karanja biodiesel blends on fuel spray, engine performance, emissions and combustion characteristics. Energy Conversion and Management, 91, 302-314. https:// doi.org/10.1016/j.enconman.2014.12.004

Agarwal, A. K., Gupta, P. and Dhar, A. (2015). Combustion, performance and emissions characteristics of a newly developed CRDI single cylinder diesel engine. Sadhana, 40(5), 1937-1954. Indian Academy of Sciences. https://doi.org/10.1007/s12046-015-0428-9

Atadashi, I. M., Aroua, M. K. and Abdul Aziz, A. (2010). High quality biodiesel and its diesel engine application: A review. Journal of Renewable and Sustainable Energy Reviews, 14(7), 1999-2008. https://doi.org/10.1016/j.rser.2010.03.020 
Atmanli, A., Ileri, E. and Yuksel, B. (2014). Experimental investigation of engine performance and exhaust emissions of a diesel engine fueled with diesel-n-butanol vegetable oil blends. Energy Convers Manage, 81, 312 21. https:// doi.org/10.1016/j.enconman.2014.02.049

Aydın, H. and Ilkılıc, C. (2015). Analysis of combustion, performance and emission characteristics of a diesel engine using low sulfur tire fuel. Fuel, 143, 373 - 82. https:// doi.org/10.1016/j.fuel.2014.11.075

Balat, M. and Balat, H. (2008). A critical review of bio-diesel as a vehicular fuel. Energy Convers Manage, 49, $2727-$ 41. https://doi.org/10.1016/j.enconman.2008.03.016

Banapurmath, N. R., Hosmath, R. S. and Tewari, P. G. (2008). Performance and Emissions Characteristics of a DI Compression Ignition Engine Operated on Honge, Jatropha and Sesame Oil Methyl Esters. Renewable Energy, 33, 1982-1988. https://doi.org/10.1016/j.renene.2007.11.012

Banapurmath, N. R., Tewari, P. G. and Vinodkumar, V. (2009). Combustion and emission characteristics of a direct injection CI engine when operated on Marotti oil methyl ester and blends of Marotti oil methyl ester and diesel. International Journal of Sustainable Engineering, 2, 192-200. https://doi.org/10.1080/19397030903089983

Banapurmath, N. R., Tewari, P. G. and Gaitonde, V. N. (2012). Experimental investigations on performance and emission characteristics of Honge oil biodiesel (HOME) operated compression ignition engine. Renewable Energy, 48, 193-201. https://doi.org/10.1016/j.renene.2012.04.010

Banapurmath, N. R., Chavan, A. S., Bansode, S. B., Sankalp, P., Naveen, G., Tonannavar, S., Keerthi K. N. and Tandale, M. S. (2015). Effect of Combustion Chamber Shapes on the Performance of Mahua and Neem Biodiesel Operated Diesel Engines. Journal of Petroleum \& Environmental Engineering. https://doi.org/10.4172/2157-7463.1000230

Bandai, M., Milo, F. and Amato, D. (2001). Experimental investigation on soot and Knox formation in a DI common rail diesel engine with pilot injection. $S A E$ paper No. 2001-01-0657.

Bari, S., Yu, C. W. and Lim, T. H. (2004). Effect of fuel injection timing with waste cooking oil as a fuel in direct injection diesel engine. Proc. Instn. Mech. Engrs. IMechE, Part D, Journal of Automobile Engineering, 218, 93-104. https://doi.org/10.1243/095440704322829209

Carlo, N., Grimalkin, L. P. and Battistoni, M. (2002). Common Rail HSDI engine combustion and emissions with fuel/Bio-derived Fuel Blends. 2002-01-0865, 1453-1460.

Dixit, S. and Rehman A. (2012). Linseed oil as a potential resource for bio-diesel: a review. Renew Sustain Energy Rev, 16, 4415-21. https://doi.org/10.1016/j.rser.2012.04.042

Gautam, A. and Agarwal, A. K. (2013). Experimental investigations of comparative performance, emission and combustion characteristics of a cotton seed biodiesel-fueled four-stroke locomotive diesel engine. Int J Engine Res, 14(4), 354-72. https://doi.org/10.1177/1468087412458215

Grimaldi, C., and Postrio, L. (2000). Experimental Compression between Conventional and Bio-derived Fuels Sprays from a common Rail injection System. SAE, 2000-01-125, 1501-1513.

Henein, N. A., Lai, M-C., Singh, I. P., Zhong, L. and Han, J. (2002). Characteristics of a common rail diesel injection system under pilot and post injection modes. SAE paper No. 2002-01-0218, 597-609. https://doi.org/10.4271/2002-01-0218

Hountalas, D. T., Kouremenos, D. A., Binder, K. B., Raab, A. and Schnabel, M. H. (2001). Using advanced Injection timing and EGR to Improve DI engine efficiency at Acceptable NO and Soot levels. Society of Automotive Engineers, Paper No.: 2001-01-0199.

Iorio, S. O., Mancaruso, E. and Vaglieco, B. M. (2012), Characterization of Soot Particles Produced in a Transparent Research CR DI Diesel Engine Operating with Conventional and Advanced Combustion Strategies. Aerosol Science and Technology, 46(3), 272-286. https:// doi.orig/10.1080/02786826.2011.620647

Jaichandar, S. and Annamalai, K. (2012). Effects of open combustion chamber geometries on the performance of pongamia biodiesel in a DI diesel engine. Fuel, 98, 272-279. https://doi.org/10.1016/j.fuel.2012.04.004

Jaichandar, S. P., Kumar, S. and Annamalai, K. (2012). Combined effect of injection timing and combustion chamber geometry on the performance of a biodiesel fueled diesel engine. Energy, 47(1), 388-394. https://doi.org/10.1016/j.energy.2012.09.059

Jaichandar, S. and Annamalai, K. (2013). Combined Impact of Injection Pressure and Combustion Chamber Geometry on the performance of a biodiesel fueled diesel engine. Energy, 55, 330-339. https://doi.org/10.1016/j.energy.2013.04.019

Kannan, D., Pachamuthu, S., Nurun, N. M., Hustad, J. E. and Lovas, T. (2012). Theoretical and experimental investigation of diesel engine performance, combustion and emissions analysis fuelled with the blends of ethanol, diesel and Jatropha methyl ester. Energy Convers Manage, 53, 322-31. https://doi.org/10.1016/j.enconman.2011.09.010

Karra, P. K. and Song-Charng, K. (2010). Experimental study on effects of nozzle holes geometry on achieving low diesel engine emissions. Journal of Engineering for Gas Turbines and Power, 132(2), 022802. https://doi.org/10.1115/1.3124791 
Karthikeyan, S., Prabhakaran, T. D. and Prathima, A. (2018). Environment effect of La2O3 nano-additives on microalgae-biodiesel fueled CRDI engine with conventional diesel. Energy Sources, Part A: Recovery, Utilization, and Environmental Effects, 40(2), 179-185. https:/ / doi.orig/10.1080/15567036.2017.1407843

Kevin, C. S. (2000). Simultaneous reduction of NOx and Particulate emissions by using multiple injections in a small diesel engine. SAE paper No. 2000-01-3084, 1-10.

Khandal, S. V., Banapurmath, N. R., Gaitonde, V. N. and Hosmath, R. S. (2015). Effect of Number of Injector Nozzle Holes on the Performance, Emission and Combustion Characteristics of Honge Oil Biodiesel (HOME) Operated DI Compression Ignition Engine. Journal of Petroleum \& Environmental Engineering.

Khandal, S. V., Banapurmath, N. R., Gaitonde, V. N. and Yaliwal, V. S. (2018). Common Rail Direct Injection Mode of CI Engine Operation with Different Injection Strategies - A Method to Reduce Smoke and NOx Emissions Simultaneously. European Journal of Sustainable Development Research, 2(2), 15. https://doi.org/10.20897/ejosdr/76884

Kumar, V. (2017). Experimental investigation of piston bowl geometry effects on performance and emissions characteristics of diesel engine at variable injection pressure and timings. International Journal of Ambient Energy, ISSN: 0143-0750 (Print) 2162-8246.

Labeckas, G. and Slavinskas, S. (2006). The effect of rapeseed oil methyl ester on direct injection diesel engine performance and exhaust emissions. Energy Convers Manage, 47, 1954-67. https://doi.org/10.1016/j.enconman.2005.09.003

Lahane, S. and Subramanian, K. A. (2014). Impact of nozzle holes configuration on fuel spray, wall impingement and NO x emission of a diesel engine for biodiesel-diesel blend (B20). Applied Thermal Engineering, 64(1), 307314. https://doi.org/10.1016/j.applthermaleng.2013.12.048

Mamilla, V. R., Mallikarjun, M. V. and Rao, G. L. N. (2013). Effect of Combustion Chamber Design on a DI Diesel Engine Fuelled with Jatropha Methyl Esters Blends with Diesel. Procedia Engineering, 64, 479 - 490. https://doi.org/10.1016/j.proeng.2013.09.122

Mani, M., Nagarajan, G. and Sampath, S. (2011). Characterization and effect of using waste plastic oil and diesel fuel blends in compression ignition engine. Energy, 36, 212-219. https://doi.org/10.1016/j.energy.2010.10.049

Mobasheri, R. and Zhijun, P. (2013). CFD Investigation of the Effects of Re-Entrant Combustion Chamber Geometry in a HSDI Diesel Engine. World Academy of Science, Engineering and Technology. International Journal of Mechanical, Aerospace, Industrial, Mechatronic and Manufacturing Engineering, 7(4), 770-780.

Murugesan, A., Umarani, C., Subramanian, R. and Nedunchezhian, N. (2009). Bio-diesel as an alternative fuel for diesel engines-A Review. Renewable and Sustainable Energy Reviews, 13(3), 653-662. https://doi.org/10.1016/j.rser.2007.10.007

Naik, S. N., Vaibhav, V., Goud Prashant, K., Rout, A. and Dalai, K. (2010). Production of first- and secondgeneration biofuels: A comprehensive review. Renewable and sustainable energy reviews, 14, 578-597. https://doi.org/10.1016/j.rser.2009.10.003

Pratoomyod, J. and Laohalidanond, K. (2013). Performance and Emission Evaluation of Blends of Diesel fuel with Waste Plastic Oil in a Diesel Engine. IJESIT, 2(2).

Qi, D. H., Yang, K., Zhang, D., Chen, B., Wei, Q. and Zhang, C. H. (2017). Experimental investigation of a turbocharged CRDI diesel engine fueled with Tung oil-diesel-ethanol micro emulsion fuel. Renewable Energy, 113, 1201-1207. https://doi.org/10.1016/j.renene.2017.06.105

Rajashekhar, C. R., Chandrashekar, T. K., Umashankar, C. and Kumar, R. H. (2012). Studies on effects of combustion chamber geometry and injection pressure on biodiesel combustion. Transactions of the Canadian Society for Mechanical Engineering, 36(4), 429-438. https:/ / doi.org/10.1139/tcsme-2012-0030

Rosli, A. B., Semin, A. and Rahim, I. (2008). Fuel injection pressure effect on performance of direct injection diesel engines based on experiment. American Journal of Applied Sciences, 5, 197- 202. https://doi.org/10.3844/ajassp.2008.197.202

Roy, M. M. (2009). Effect of fuel injection timing and injection pressure on combustion and odorous emissions in DI diesel engine. Journal of Energy Resources Technology, ASME Transactions, 131, 1-8. https://doi.org/10.1115/1.3185346

Sharma, A. and Murugan, S. (2013). Investigation on the behavior of a DI diesel engine fuelled with Jatropha Methyl Ester (JME) and Tyre Pyrolysis Oil (TPO) blends. Fuel, 108, 699-708. https://doi.org/10.1016/j.fuel.2012.12.042

Sharma, A. and Murugan, S. (2015). Combustion, performance and emission characteristics of a DI diesel engine fuelled with non-petroleum fuel: A study on the role of fuel injection timing. Journal of the Energy Institute, 88, 364-75. https://doi.org/10.1016/j.joei.2014.11.006 
Shetty, A. D., Kumar, R. R., Kumarappa, S. and Antony, A. J. (2016). September. Study on Conversion of Municipal Plastic Wastes into Liquid Fuel Compounds, Analysis of Crdi Engine Performance and Emission Characteristics. In IOP Conference Series: Materials Science and Engineering, 149(1), p. 012223. IOP Publishing. https://doi.org/10.1088/1757-899X/149/1/012223

Shivashimpi, M. M., Alur, S. A. and Topannavar, S. N. (2016). Effect of Cylindrical combustion chamber shape on the performance and Emission Characteristics of C.I. Engine Operated on Pongamia. Joumal of Advances in science and Technology, 12(25), (Special Issue), December, ISSN 2230-9659.

Shivashimpi, M. M., Alur, S. A., Topannavar, S. N. and Dodamani, B. M. (2017). Combined Effect of Cylindrical Combustion Chamber Shape and Nozzle Geometry on The Performance and Emission Characteristics Of C.I. Engine Operated On Pongamia. Proceedings of the 1st International and $18^{\text {th }}$ national ISME Conference on Mechanical Engineering: Enabling Sustainable Development, NIT Warangal, India February 23rd - 25th, pp-113.

Shivashimpi, M. M., Alur, S. A., Topannavar, S. N. and Dodamani, B. M. (2018). Combined effect of combustion chamber shapes and nozzle geometry on the performance and emission characteristics of C.I. engine operated on Pongamia. Energy, 154, 17-26. https://doi.org/10.1016/j.energy.2018.04.097

Shivashimpi, M. M., Banapurmath, N. R., Alur, S. A. and Khandal, S. V. (2018). Effect of Combustion Chamber Shapes, Nozzle Holes Geometries, Injection Pressures and Injection Timing on the Performance Diesel Engine Fueled with Palm Oil Methyl Ester. European Journal of Sustainable Development Research, 2(3), 35. https://doi.org/10.20897/ejosdr/2667

Shukla, P. C., Gupta, T. and Agarwal, A. K. (2014). A comparative morphological study of primary and aged particles emitted from a biodiesel (B20) vis-à-vis diesel fuelled CRDI engine. Aerosol Air Qual. Res, 14, 934-942. https://doi.org/10.4209/aaqr.2013.05.0162

Shukla, R. S., Shetty, A. D. and Antony, A. J. (2016). Performance and emission characteristics of CRDI engine working on plastic oil. Indian journal of science and technology, 9(45).

Soorajith, R. and Vinu, H. R. (2004). Electronic Diesel control-A Strategy for Euro 3 optimization. SAE 2004 Indian Mobility Conference, Proceedings of third international conference, 2004-28-0025, 164-168. https://doi.org/10.4271/2004-28-0025

Srivastava, P. K. and Verma, M. (2008). Methyl ester of karanja oil as alternative renewable source energy. Fuel, 87, 1673-7. https://doi.org/10.1016/j.fuel.2007.08.018

Sukumar, P., Jegan, R., Balasubbramanian, K. and Nagarajan, G. (2009). Effect of injection pressure on performance, emission and combustion characteristics of high linolenic linseed oil methyl ester in a DI Diesel engine. Renewable Energy, 34, 1227 -33. https://doi.org/10.1016/j.renene.2008.10.001

Suresh, G., Kamath, H. C. and Banapurmath, N. R. (2013). Effect of Injection timing, Injector opening pressure and Nozzle geometry on the performance of Cotton seed oil methyl ester fuelled diesel engine. International Journal of Sustainable Engineering, Francis and Taylor Publications, 7, 82-92.

Tao. F., Liu. Y., Rempel Ewert. B. H., Foster. D. E., Reitz. R. D., Choi. D. and Miles, P. C. (2005). Modelling the effect of EGR and retarded injection on soot formation in a high-speed diesel injection (HSDI) diesel engine using a multi-step phenomenological soot model. Society of Automotive Engineers, Paper No.: 2005 -01-0121.

Tiegang, F., Chia-Fon and Lee, F. (2009). Bio-diesel effects on combustion processes in an HSDI diesel engine using advanced injection strategies. Proceedings of the combustion Institute, 32, 2785-2792.

Wategave, S. P., Sawant, M. S., Tandale, M. S., Suresh, G., Yaliwalc, V. S., Banapurmath, N. R. and Tewari, P. G. (2014). Effect of injection timing, injector opening pressure and nozzle geometry on the performance of a compression ignition engine operated on non-edible oil methyl esters from different sources. International Joumal of Sustainable Engineering, 7(1), 71-81. https:// doi.org/10.1080/19397038.2013.777134

Williams, P. T. (2013). Pyrolysis of waste tyres: A review. Waste Management, 33, 1714-1728. https://doi.org/10.1016/j.wasman.2013.05.003

Yaliwal, V. S., Banapurmath, N. R., Gireesh, N. M., Hosmath, R. S., Donateo, T. and Tewari, P. G. (2016). Effect of nozzle and combustion chamber geometry on the performance of a diesel engine operated on dual fuel mode using renewable fuels. Renewable Energy, 93, 483-501. https://doi.org/10.1016/j.renene.2016.03.020 